\title{
Theory-driven development of a medication adherence intervention delivered by eHealth and transplant team in allogeneic stem cell transplantation: the SMILe implementation science project
}

\author{
Janette Ribaut ${ }^{1,2}$, Lynn Leppla ${ }^{1,3}$, Alexandra Teynor ${ }^{4}$, Sabine Valenta ${ }^{1,2}$, Fabienne Dobbels ${ }^{1,5}$, Leah L. Zullig ${ }^{6,7}$,
} Sabina De Geest ${ }^{1,5^{*}}$ (D) on behalf of the SMILe study team

\begin{abstract}
Background: Medication adherence to immunosuppressants in allogeneic stem cell transplantation (alloSCT) is essential to achieve favorable clinical outcomes (e.g. control of Graft-versus-Host Disease). Over 600 apps supporting medication adherence exist, yet they lack successful implementation and sustainable use likely because of lack of end-user involvement and theoretical underpinnings in their development and insufficient attention to implementation methods to support their use in real-life settings. Medication adherence has three phases: initiation, implementation and persistence. We report the theory-driven development of an intervention module to support medication adherence (implementation and persistence phase) in alloSCT outpatients as a first step for future digitization and implementation in clinical setting within the SMILe project (Development, implementation and testing of an integrated care model in allogeneic SteM cell transplantatlon facilitated by eHealth).

Methods: We applied Michie's Behavior Change Wheel (BCW) and the Capability-Opportunity-Motivation and Behavior (COM-B) model using three suggested stages followed by one stage added by our team regarding preparation for digitization of the intervention: (I) Defining the problem in behavioral terms; (II) Identifying intervention options; (III) Identifying content and implementation options; (IV) SMILe Care Model Prototype Development. Scientific evidence, data from a contextual analysis and patients'/caregivers' and clinical experts' inputs were compiled to work through these steps.

(Continued on next page)
\end{abstract}

\footnotetext{
* Correspondence: sabina.degeest@unibas.ch

'Department Public Health, Faculty of Medicine, Institute of Nursing Science, University of Basel, Bernoullistrasse 28, 4056 Basel, Switzerland

${ }^{5}$ Academic Center for Nursing and Midwifery, Department of Public Health and Primary Care, University of Leuven, 3000 Leuven, Belgium

Full list of author information is available at the end of the article
}

(c) The Author(s). 2020 Open Access This article is licensed under a Creative Commons Attribution 4.0 International License, which permits use, sharing, adaptation, distribution and reproduction in any medium or format, as long as you give appropriate credit to the original author(s) and the source, provide a link to the Creative Commons licence, and indicate if changes were made. The images or other third party material in this article are included in the article's Creative Commons licence, unless indicated otherwise in a credit line to the material. If material is not included in the article's Creative Commons licence and your intended use is not permitted by statutory regulation or exceeds the permitted use, you will need to obtain permission directly from the copyright holder. To view a copy of this licence, visit http://creativecommons.org/licenses/by/4.0/ The Creative Commons Public Domain Dedication waiver (http://creativecommons.org/publicdomain/zero/1.0/) applies to the data made available in this article, unless otherwise stated in a credit line to the data. 
(Continued from previous page)

Results: (I) Correct immunosuppressant taking and timing were defined as target behaviors. The intervention's focus was determined within the COM-B dimensions Capability (lack of knowledge, lack of routine), Opportunity (lack of cues, interruptions in daily routine) and Motivation (lack of problem solving, trivialization). (II) Five intervention functions were chosen, i.e. education, training, modelling, persuasion and enablement. (III) Twenty-four behavior change techniques were selected, e.g., goal setting, action planning and problem solving. (IV) Finally, seventeen user stories were developed to guide the SMILeApp's software development process.

Conclusion: Our example on the theory-driven development of an intervention module in allosCT delivered by eHealth and transplant team using a rigorous $3+1$-stage approach based on BCW, COM-B and agile software development techniques, can be used as methodological guidance for other eHealth intervention developers. Our approach has the potential to enhance successful implementation and sustained use of eHealth solutions in real-life settings.

Keywords: Allogeneic hematopoietic stem cell transplantation, Medication adherence, Intervention development, Behavior change wheel, Theory-driven, eHealth intervention, Implementation science

\section{Background}

Allogeneic stem cell transplant (alloSCT) is a wellestablished, potentially curative treatment modality for various malignant and non-malignant hematological diseases in which a patient's diseased blood-producing system is replaced by that of a healthy person [1]. These patients' complex care needs demand innovation in care delivery [2]. As information technology widely available through smartphones has the potential to support patients in adopting and developing essential behaviors such as those surrounding medication adherence $[2,3]$, the National Institutes of Health Hematopoietic Cell Transplantation Late Effects Initiative [2] recommend that related interventions include the support of eHealth solutions.

Medication adherence is defined as "The process by which patients take their medications as prescribed, composed of initiation, implementation and discontinuation" (Fig. 1) ( [5], p. 697). Initiation means that the patient starts taking a prescribed medication. Implementation means the correspondence of a patient's actual dosing compared to the prescription. Implementation ${ }^{1}$ errors can take the form of late, skipped, extra, or reduced doses or 'drug holidays' (skipping several doses in a row). If the patient quits the prescribed medication for any reason(s), this is called discontinuation. The time span between the first and last dose is called persistence [5].

Medication adherence is vital regarding clinical outcomes in patients following alloSCT $[6,7]$ : as many as $80 \%$ of alloSCT patients develop an acute or chronic Graft-versus-Host Disease (GvHD) [8, 9], a serious complication in which the donor's immune cells attack the recipient's body [1] leading to increased morbidity and mortality [8-11]. Although there is limited evidence and the few existing studies did not distinguish between the three medication adherence phases (initiation,

\footnotetext{
${ }^{1}$ Although implementation adherence uses the same word, this does not equate with implementation in the context of implementation science.
}

implementation, persistence), we found medication adherence to immunosuppressants in alloSCT essential to prevent or treat complications such as acute and chronic GvHD $[12,13]$. The correlation is extremely compelling: In patients without chronic GvHD only $15.6 \%$ showed medication non-adherence to immunosuppressants while in patients with mild GvHD already $66.7 \%$ were non-adherent. In patients with moderate GvHD 74.1\% showed medication non-adherence and in patients with severe GvHD even $88.9 \%$ were non-adherent [12]. As alloSCT receive their first doses of immunosuppressants during their hospitalization, the initiation phase of adherence is not an issue [6,7]; adherence enhancing interventions need to focus on post-discharge implementation and persistence of medication intake [12]. While available evidence on medication adherence in alloSCT populations is limited, we know that the prevalence of overall nonadherence to immunosuppressants in adult alloSCT patients is $64.6 \%$ with $33.3 \%$ taking, $61.2 \%$ timing and $4.1 \%$ dosing non-adherence, $3.2 \%$ drug holidays and $3.1 \%$ discontinuation [12].

Findings from randomized controlled trials (RCT) in other chronic disease areas, including solid organ transplantation, positively link behavioral interventions using eHealth with improvements in medication adherence [14-16], unplanned inpatient acute care admissions [16], costs [16], general health outcomes (e.g., blood glucose or blood pressure) [17] and overall quality of life $[16,17]$. The most successful behavior change techniques (BCTs) (i.e., active intervention elements) used in these trials were self-monitoring of and feedback on medication intake [15-19], reminder cues [15, 18, 19], goal setting, action planning and problem solving [14-17, 20]. To date, though, no interventions focusing on these elements have been developed and tested in alloSCT.

Moreover, compared to the wealth of findings emerging from trials, comparatively little information is available on successful implementation and subsequent evaluation of medication adherence interventions in 


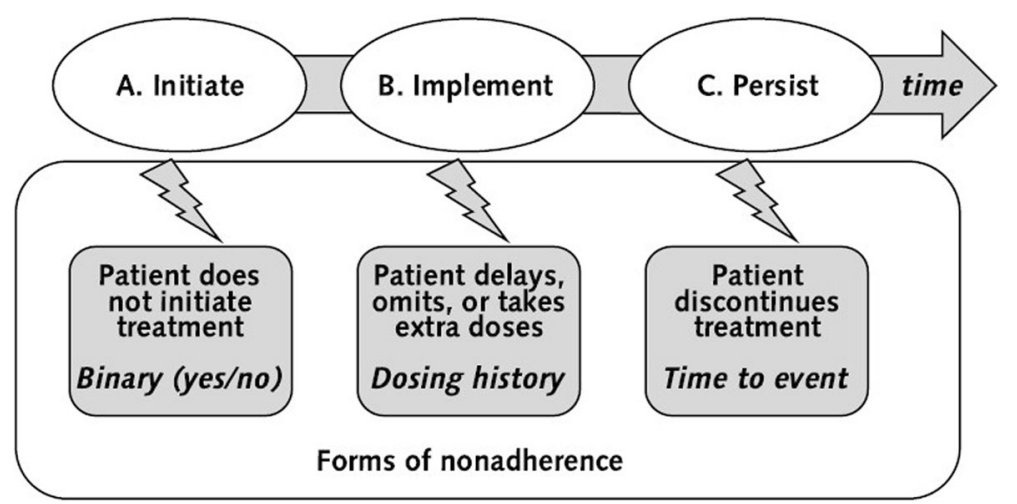

Fig. 1 Concept of medication adherence with initiation, implementation and persistence [4], based on [5]. From Annals of Internal Medicine, De Geest S, Zullig LL, Dunbar-Jacob J, Helmy R, Hughes DA, Wilson IB, Vrijens B, ESPACOMP Medication Adherence Reporting Guideline (EMERGE), 169, 1, 30-35. Copyright@ [2018] American College of Physicians. All Rights Reserved. Reprinted with the permission of American College of Physicians, Inc

general and eHealth supported behavioral interventions in particular in real-world settings. A 2018 review on high quality medication adherence intervention trials in different patient populations found that most of them did not report on essential implementation research elements, hindering the adaptation and implementation of trial findings into real-world setting [21]. Another 2018 review paper found 681 apps to support medication adherence in the Apple App and Google Play Stores [22]. However, only 84 (12.3\%) of these were developed by or in collaboration with health care professionals, only eight $(1.2 \%)$ were theory-based, and none reported patient involvement in their development process [22]. And regardless of whether they were developed based on a specific theory, roughly two-thirds contained zero to two BCTs. Of apps including BCTs, 96\% included reminders - which are often unneeded or unwanted by patients [23]. Some higher-value BCTs such as self-monitoring or feedback on behavior were included in a minority (36-39\%), but techniques such as social support or information about the health consequences were very rare (1-2\%) [23]. Combined with developers' general omission of end-user involvement (especially from patients) $[22,24]$, general shortages both of theoretical underpinnings $[2,25]$ and of contextual information to adapt eHealth interventions for implementation in specific settings [26-28] very likely contribute to two major concerns: 1) More than two-thirds of patients who use health-related apps abandon them within 3 months [24]; and 2) Very few health behavior support interventions are ever successfully implemented in real-world settings $[15,18,19,29-32]$.

In order to support post-alloSCT medication adherence effectively and sustainably, eHealth supported medication adherence interventions need to be planned from start to finish with a clear focus on one overarching outcome: implementation in daily clinical alloSCT practice. Accordingly, our major goal with this paper is to report the development of an eHealth facilitated care medication adherence module (implementation and persistence phase) for alloSCT. To do so, we have employed the Behavioral Change Wheel (BCW) and the CapabilityOpportunity-Motivation and Behavior (COM-B) model both of which, unlike other behavioral theories (e.g. Theory of Planned Behavior and Health Belief Model [33]), provide multilevel perspectives and include emotional factors [34]. In addition, we have developed user stories that facilitate the translation of research findings first to digitalization of the intervention, then to standard practice among both clinicians and patients.

\section{Methods/results}

The SMILe project

This work is part of the international, interdisciplinary, multi-phase, multicenter SMILe project, which aims at reengineering follow-up care to patients with alloSCT into an integrated care model first at the University Medical Center Freiburg, Germany and in a second step at the University Hospital of Basel, Switzerland (https:// nursing.unibas.ch/de/forschungsprojekte/forschung/forschung/smile/). The SMILe integrated care model builds on the eHealth Enhanced Chronic Care Model (eCCM) [3]. Its major aim is to introduce follow-up based on a chronic care model by providing self-management support, optimizing delivery system design (e.g., increasing continuity of care), clinical decision support and clinical information systems.

As these functions involve considerable time and expertise, we recommend the introduction of a Carecoordinator (CC) to perform them, along with the use of a SMILe e-platform including the SMILeApp and the SMILeCare monitoring component for the CC. For the 
first year post-alloSCT, in addition to connecting patients to the $\mathrm{CC}$ in the transplant center, the app will allow patients to assess relevant biomedical and behavioral parameters on a continuous basis.

Four intervention modules are integrated to support self-management and promote alloSCT patients' target health behaviors: Monitoring and Follow-Up, Infection Prevention, Physical Activity and Medication Adherence. This paper reports on the development of the medication adherence module. This patient-centered, theorybased development approach will increase the likelihood of adoption and implementation in practice.

\section{Guiding methodology}

Our intervention development process used an iterative approach applying the three stages of the $\mathrm{BCW}$ and one additional stage for the SMILe Care Model Prototype Development (Fig. 2), with each stage of execution reviewed by the entire SMILe research team [34, 35]. The various stages and steps will be further described in the next section ("The BCW"). Intervention development was informed by data from our previously performed multi-methods contextual analysis and evidence. Contextual analysis refers to the mapping of relevant multilevel contextual factors for the implementation of an intervention, e.g. local infrastructure, leadership, motivation of the stakeholders [27]. This means the inquiry of a specific context (in our case alloSCT follow-up care at the University Hospital of Freiburg, Germany), practice patterns as well as the attitudes and behaviors of all parties involved. Our preliminary work included such a contextual analysis using a cross-sectional quantitative survey of 60 alloSCT patients and five clinicians working in alloSCT. That analysis also included qualitative data, namely individual interviews with another ten alloSCT patients and three alloSCT clinician focus groups. The detailed description of the methods and results of this contextual analysis were recently published elsewhere [36]. It studied all relevant contextual aspects of the proposed integrated model of care, e.g., socio-cultural aspects at the micro (i.e., patient) and meso (i.e., transplant center) levels. Further, we examined the feedback of 21 stem cell transplant patients and eleven caregivers collected during three feedback rounds in Freiburg im Breisgau (Germany). Both, allogeneic and autologous stem cell transplant recipients were invited to give feedback as they participated a shared self-help group. We presented them our preliminary results and asked them to rank e.g. the importance of barriers to medication adherence or whether the proposed BCTs were feasible for them. The patients' and caregivers' feedback was included in the further development of the intervention. In addition, we reviewed existing evidence on 1) definition, prevalence and consequences of medication non-adherence in alloSCT (quantitative, appendix search diagram 1), 2) barriers and facilitators of medication adherence in alloSCT and solid organ transplantation (qualitative, appendix search diagram 2), and 3) existing interventions to support medication adherence in alloSCT and solid organ transplantation (quantitative, appendix search diagram 3). Because evidence in alloSCT is very limited, but medication adherence tasks are similar in alloSCT and solid organ transplant patients, we also included pertinent literature from solid organ transplantation.

\section{The BCW}

One particularly rigorous and widely useful system of developing and implementing behavior change interventions is the $\mathrm{BCW}[37,38]$. Combining 19 behavior change frameworks, the $\mathrm{BCW}$ is used to identify, understand and explain behaviors and their influencing factors. It consists of three stages: 1) understanding the behavior, 2) identifying intervention options and 3)

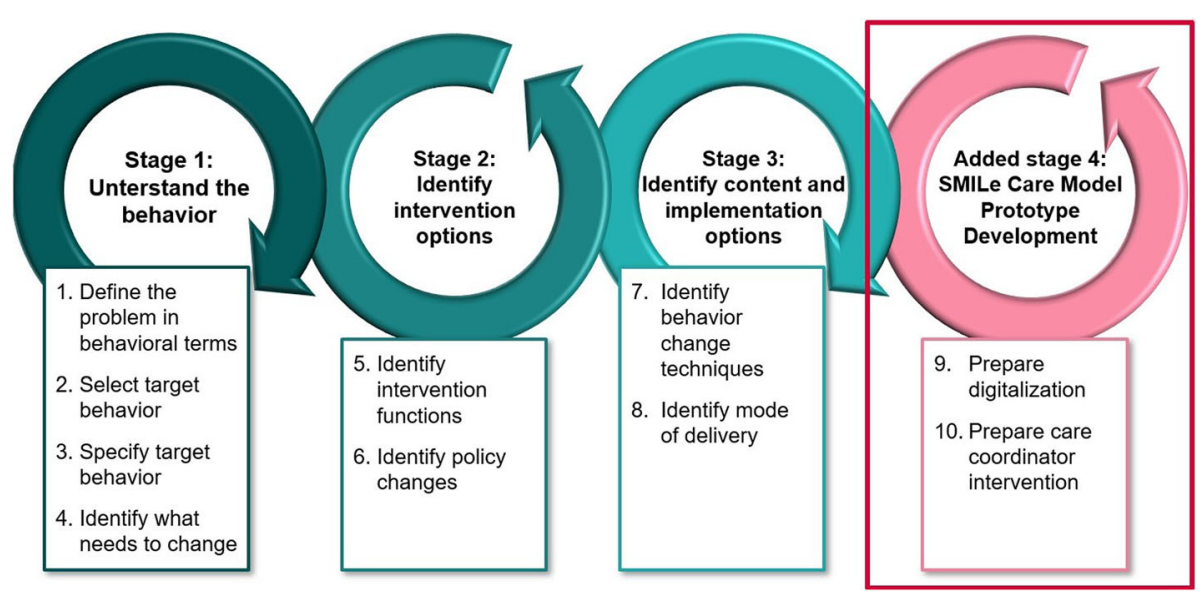

Fig. 2 The 3 stages and 8 steps of the BCW [34] with our added stage 4 (self-developed figure) 
identifying content and implementation options, which are further divided into eight steps (Fig. 2) [34].

\section{BCW stage 1: understand the behavior}

\section{Step 1: define the problem in behavioral terms}

Before attempting to modify a behavior it is necessary to understand it in detail and to identify possible starting points for change [34]. Therefore, the first step of the $\mathrm{BCW}$ is to define the problem in behavioral terms using three leading questions: What is the behavior?; Where does it occur?; and Who is involved?

In order to answer these questions, we first deepened our understanding of the problem by performing a scoping review of studies reporting definitions, prevalences and consequences of medication non-adherence in alloSCT (appendix, search diagram 1). From the twelve studies we identified, we extracted information on definition and relevance of medication non-adherence.

Results. Particularly regarding immunosuppressive regimes we found medication adherence essential in alloSCT to prevent or treat complications such as acute and chronic GvHD [12, 13]. However, almost $65 \%$ of participating patients struggled with medication intake, especially immunosuppressants taking and timing (implementation phase of medication adherence) [12] (Table 1).

The contextual analysis data of our preliminary work (see Guiding methodology section) [36] indicated that
alloSCT patients were aware of the importance of following the medication regimen closely, especially when family, friends and caregivers were involved in medication management. According to clinicians, medication adherence was not systematically assessed at the studied transplant center. They also acknowledged a need for a person such as an Advanced Practice Nurse (APN) to coordinate follow-up, i.e., a CC [36]. The insights obtained from the literature review and contextual analysis enabled us to define the problem in behavioral terms (Table 1).

\section{$B C W$ step 2: select target behavior}

The second step is to create a list of behavioral components known to influence the problem. From this list, behaviors are selected based on their expected impact (when improved) on target outcomes, the likelihood that they can be changed, the extent of expected spillover effects on other health behaviors and their measurability [34].

Results. In the literature search we identified 12 quantitative studies about prevalence and consequences of different behavioral components (appendix, search diagram 1). Based on the information from that literature review, we compiled a list of potential target behaviors that influence implementation and persistence adherence. For example, taking, timing and dosing immunosuppressants correctly (three behaviors), following food considerations concerning immunosuppressants and not taking drug holidays (implementation dimension). From this list, we selected correct taking and timing of immunosuppressants as the two most

Table 1 Definition of the problem in behavioral terms

\begin{tabular}{ll}
\hline Leading question & Possible answer \\
\hline $\begin{array}{l}\text { What is the problem/ } \\
\text { behavior? }\end{array}$ & Medication non-adherence, which is associated with poor clinical and economic outcomes [20, 39], pervades all chronic- \\
& ally ill patient populations [12, 13, 29, 40]. Post-alloSCT patients are chronically ill. With a mean of 12 medications [41], \\
& their medication regimen is complex. Most important medications in the 1st year post-alloSCT are immunosuppressants \\
& and anti-infectious medications. Co-medications (e.g., antibiotics, antivirals, fungicide) are essential to prevent and treat in- \\
& fections [42]. \\
& Using the ABC taxonomy, medication adherence consists of three interrelated phases: initiation, implementation and \\
& persistence [5], the latter two being relevant after alloSCT. Implementation adherence includes correct taking, timing, \\
& dosing, no drug holidays and correct food considerations (e. g., no grapefruit juice) [5, 12]. \\
& While available evidence on medication adherence in alloSCT populations is limited, we know that the prevalence of \\
& overall non-adherence to immunosuppressants in adult alloSCT patients is $64.6 \%: 33.3 \%$ taking non-adherence, 61.2\% tim- \\
& ing non-adherence, 4.1\% dosing non-adherence, 3.2\% drug holidays and 3.1\% discontinuation [12]. Non-adherence to im- \\
& munosuppressants is strongly associated with GvHD [12]. Less is known in view of co-medication. And while only 57\% of \\
& the adult alloSCT patients report perfect medication adherence to all prescribed drugs after alloSCT [43], non-adherence \\
can be quite selective, e.g., in one study 17\% of subjects discontinued antifungal prophylaxis prematurely [44]. & Therefore, it is crucial to optimize adherence, especially to immunosuppressants, in adults after alloSCT (implementation \\
& and persistence).
\end{tabular}

Where does it occur? After alloSCT, non-adherence occurs at the patients' homes and / or where they are at the scheduled time of medication intake.

Our contextual analysis showed that alloSCT patients within the target setting understood the importance of following their medication regimen. According to clinicians, though, medication adherence was not systematically assessed at the target transplant center. If assessed, asking the patients for intake, monitoring blood-levels or checking for rejection signs were reported to be the most used practices. Clinicians also noted a need for a qualified person, e.g., an Advanced Practice Nurse or dedicated CC, to coordinate follow-up [36].

Who is involved? The entire health and health-related network surrounding adult patients after alloscT (family, friends, health care profesWho is our target group? sionals, ...) [36].

Community dwelling adult post-alloSCT patients 
prevalent and important target behaviors. This selection was guided by a systematic rationale: changing these behaviors was expected to have the best overall combination of direct impact on clinical outcomes, spillover effects on other behaviors, e.g., taking no drug holidays, and ease of measurement (Table 2). We based our rating system (i.e., ++ very promising, + promising, \pm not promising but worth considering, - unacceptable) on evidence from the literature and the research team's clinical expertise.

\section{$B C W$ step 3: specify the target behavior}

As the third step is to examine the selected behaviors (in our case, two) both from the patient's perspective and within the context of the surrounding system [34], we specified each in terms of who, what, when, where, how, how often and with whom they occurred. This choice of details was based on previously evaluated evidence from the literature [12, 13, 41], but mainly on our contextual analysis [36] and our research team's clinical expertise.

Results. The resulting details (Table 3) allowed identification of target behaviors [34].

\section{$B C W$ step 4: identify what needs to change}

The fourth step is to identify what needs to change by analyzing risk factors not only at the individual but also higher in the system. For this step, the COM-B model (Fig. 3) - the center of the BCW (Fig. 4) - supports behavioral analysis very well, as it acknowledges that behaviors such as medication non-adherence are influenced by the physical and psychological capability, physical and social opportunity as well as reflective and automatic motivation. Capability is the capacity to engage in a certain health behavior (e.g., medication intake); opportunity refers to factors external to the individual that make behavior possible; and Motivation refers to the brain processes - whether reflective or unconscious - that direct behavior. Two common examples of capability are cognitive functionality (psychological capability) and the physical capability to swallow medication. Opportunities may lie in the accessibility of the medication (physical opportunity) or support from a partner (social opportunity); and motivational aspects would include attitudes about the medication, such as beliefs about its efficacy (reflective motivation) or treatment fatigue (automatic motivation).

Of course, capability and opportunity also affect motivation, and the behavior itself influences all three adherence components (Fig. 3). As an ecologic model (i.e., involving factors on the patient, health care provider, health care organization and health care system level), the $\mathrm{BCW}$ is helpful in understanding behaviors' determinants and emotional drivers and provides the basis for the following steps.

In addition, the COM-B can be combined with the Theoretical Domains Framework (TDF) [34], which synthesizes multiple behavioral theories and includes 14 domains of behavioral influence (Fig. 4). Each domain represents theoretical constructs such as knowledge, skills or beliefs and relates to one COM-B component. Used together, the COM-B and the TDF allow a behavioral diagnosis, which facilitates the choice of effective behavior change interventions [34].

Where exactly to initiate behavior change was determined partly by the results of the contextual analysis and partly by qualitative evidence. We located the latter via a scoping review for qualitative findings on alloSCT patients' and clinicians' perspectives, barriers and facilitators to medication adherence. Due to limited evidence

Table 2 List of possible target behaviors

\begin{tabular}{|c|c|c|c|c|}
\hline Possible target behavior & $\begin{array}{l}\text { Impact of } \\
\text { behavior } \\
\text { change }\end{array}$ & $\begin{array}{l}\text { Likelihood } \\
\text { of change }\end{array}$ & Spillover effect & Measurement \\
\hline $\begin{array}{l}\text { Correct taking of immunosuppressants (i.e. persistently reducing } \\
\text { number of missed immunosuppressants doses) }\end{array}$ & $\begin{array}{l}++ \\
(\downarrow \text { risk of GvHD } \\
[12])\end{array}$ & ++ & $\begin{array}{l}++ \text { (adherence to co- } \\
\text { medication, no drug holidays) }\end{array}$ & $++[45]$ \\
\hline Correct timing of immunosuppressants & $\begin{array}{l}++? \\
(\downarrow \text { risk of GvHD? } \\
[46,47])\end{array}$ & + & $\begin{array}{l}++ \text { (adherence to co- } \\
\text { medication, no drug holidays) }\end{array}$ & $++[45]$ \\
\hline Correct dosing of immunosuppressants & $\begin{array}{l}++ \\
(\downarrow \text { risk of GvHD } \\
[12])\end{array}$ & + & $\begin{array}{l}\text { + (adherence to co- } \\
\text { medication, no drug holidays) }\end{array}$ & $\pm[45]$ \\
\hline Performing no drug holidays & $\begin{array}{l}++ \\
(\downarrow \text { risk of GvHD } \\
[12])\end{array}$ & ++ & $\begin{array}{l}+ \text { (adherence to co- } \\
\text { medication) }\end{array}$ & $++[45]$ \\
\hline Following food considerations & $\begin{array}{l}++ \\
(\downarrow \text { risk of GvHD } \\
[12])\end{array}$ & + & $\begin{array}{l}+ \text { (considerations for co- } \\
\text { medication) }\end{array}$ & $-[45]$ \\
\hline
\end{tabular}


Table 3 Specification of target behaviors

\begin{tabular}{lll}
\hline Target behavior & Correct taking of immunosuppressants & Correct timing of immunosuppressants \\
\hline Who & Adult alloSCT patients & Adult alloSCT patients \\
What & Take immunosuppressants 2x/day & Take immunosuppressants at prescribed time \\
When & $\begin{array}{l}\text { a.m. \& p.m. } \\
\text { (at least until day 120-180, mean } 16 \text { months after alloSCT) }\end{array}$ & $\begin{array}{l}\text { e.g., } 9^{00} \& 21^{00}, \text { max. Deviation } 2 \mathrm{~h} \\
\text { (at least until day 120-180, mean } 16 \text { months after alloSCT) }\end{array}$ \\
Where & Patient location (home, work, vacation, ...) & Patient location (home, work, vacation, ...) \\
How & Swallowing pills with fluid (e.g., water, no grapefruit juice) & Swallowing pills with some fluids (e.g., water, no grapefruit juice) \\
How often & Every day & Every day \\
With whom & Alone (possibly with support of family/friends, nurse) & Alone (possibly with support of family/friends, nurse) \\
\hline
\end{tabular}

alloSCT Allogeneic stem cell transplantation

in the alloSCT population we also included literature from the solid organ transplant population (appendix, search diagram 2).

Results. According to the findings of the 16 identified qualitative studies and the contextual analysis, implementation of medication adherence is influenced by a broad set of multilevel factors, which we organized within the COM-B model (Table 4). For instance, lack of knowledge and lack of routine (Capability), lack of cues and interruptions in daily routine (Opportunity), lack of problem solving, trivialization and denial (Motivation) were identified as possible barriers to medication adherence implementation.

We crosschecked and compared our review's results with those of two recent quantitative studies on multilevel determinants of medication non-adherence in heart transplantation [62]. In addition, we analyzed data from a long-term bio-psychosocial follow-up in solid organ transplantation [64] in which our research group was involved. The results supported our previous findings.

According to the findings of the 16 identified qualitative studies $[48-61,63,65]$, the results of our contextual analysis and patient feedback, we selected the highest-priority barriers. The behavioral diagnosis findings for each domain and necessary changes are listed in Table 4.

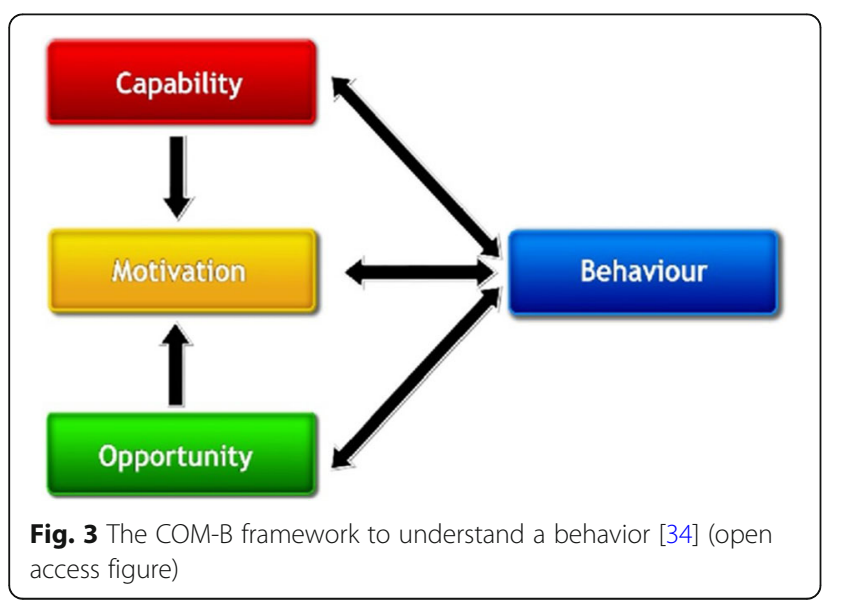

BCW stage 2: identify intervention options $B C W$ step 5: identify intervention functions

After identifying the target needs, the relevant intervention functions (Fig. 4) must be identified. The BCW lists nine of these (education, persuasion, incentivization, coercion, training, restriction, environmental restructuring, modeling, and enablement), each of which is a set of effective intervention categories with the potential to mitigate barriers to behavior change identified by the COM-B and/or TDF models.

To guide our selection, we applied the APEASE criteria (test of Affordability, Practicability, Effectiveness and cost-effectiveness, Acceptability, Side effects/safety, and Equity) [66] on each intervention function (Table 5). The identified components were rated (i.e., ++ very promising, + promising, \pm not promising but worth considering, - unacceptable) with consideration for available evidence, the research team's clinical expertise, our contextual analysis and patient feedback. The APEASE criteria were also applied in further steps, always using the same data sources mentioned here. To search for existing interventions that support medication adherence in alloSCT, we performed a systematic literature search (appendix, search diagram 3). Due to limited evidence in the alloSCT setting, we also included findings from the solid organ transplant population.

Results. According to eleven quantitative studies we identified on medication adherence-enhancing interventions, combinations of education, training, enablement, modeling, environmental restructuring and persuasion were effective functions to support medication adherence $[15,18-20]$. After considering the feasibility of each according to our contextual analysis, we excluded environmental restructuring, as this was not feasible within the SMILe project's context. We then presented the selected functions to alloSCT patients and caregivers to discuss their feasibility and usefulness. The research team applied the APEASE criteria to the functions favored by the patient and caregiver group. They found that education, training, enablement, modeling and 


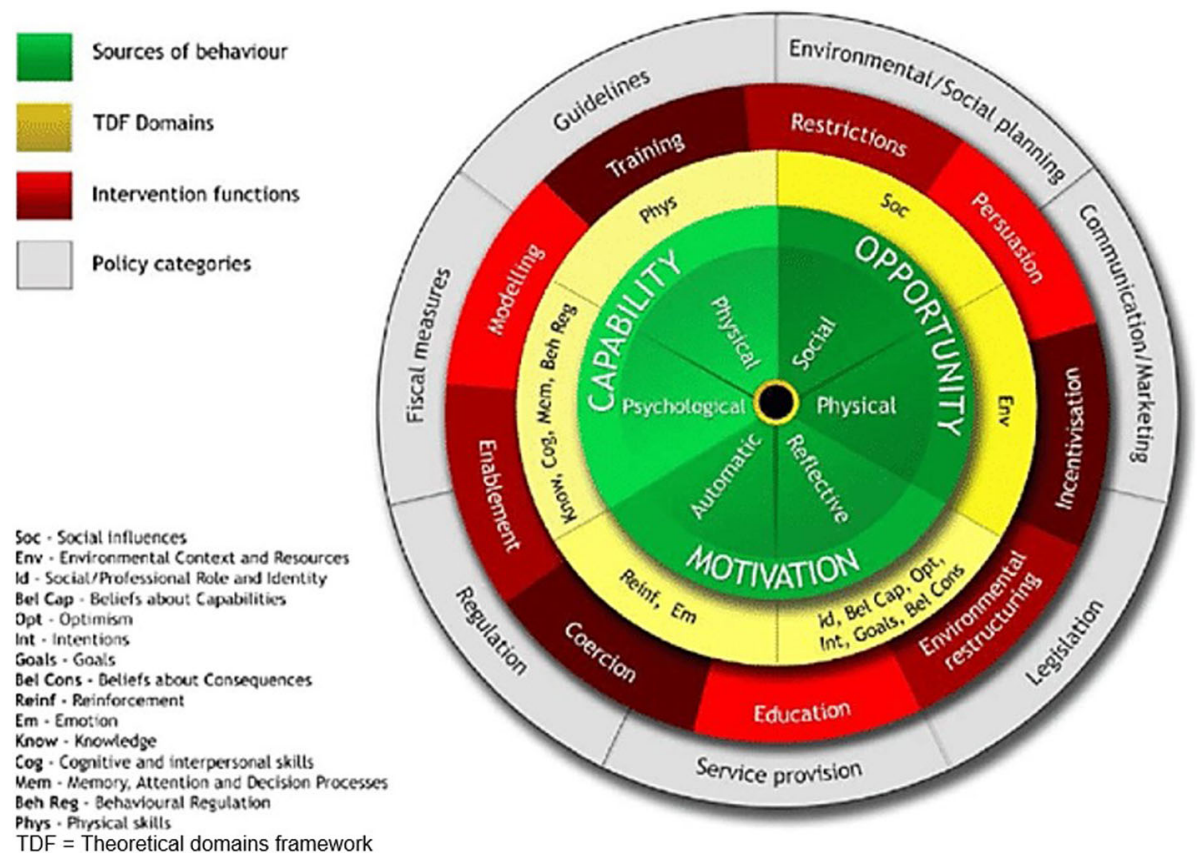

Fig. 4 The behavior change wheel [34] (open access figure)

persuasion to have the greatest potential to improve medication adherence in post-alloSCT patients (Table $5)$.

\section{$B C W$ step 6: identify policy categories}

In this step, policy categories are identified (Fig. 4). The $\mathrm{BCW}$ lists seven such categories (communication/marketing, guidelines, fiscal measures, regulation, legislation, environmental/social planning, service provision), from which researchers can choose those that will best support delivery of the intervention functions selected in step 5 [34]. We based our selection of policy categories on the results of our contextual analysis.

Results. After applying the APEASE criteria once again we selected two policy categories - regulation and service provision - as those most congruent with our chosen intervention functions (Table 6).

\section{BCW stage 3: identify content and implementation options \\ $B C W$ step 7: identify behavioral change techniques}

The seventh step is to identify BCTs, which are the active elements of an intervention. The BCT Taxonomy describes 93 BCTs, classified in 19 categories (e.g., goal setting, action planning, problem solving, information about health consequences, self-/monitoring of behavior, self-reward, punishment) to change a behavior. Thanks to the BCT Taxonomy, uniform terminology can also be used to describe intervention components, allowing replication of a study [34]. Based on the findings of the previous $\mathrm{BCW}$ steps and the data sources explained above, we selected the BCTs that we judged would best support our chosen intervention functions.

Results. In the literature search, we identified 11 quantitative studies on interventions (appendix, search diagram 3). According to the results, cognitiveeducational interventions (e.g., information and instructions) were frequent, but showed inconsistent results in enhancing medication adherence $[18,20]$. Behavioral interventions (e.g., counseling, reminders, self-monitoring and feedback on medication intake) led to significant improvements in medication adherence $[15,18-20]$. While combinations of cognitive-educational, behavioral and psychological-affective interventions showed the best improvements, even these results were inconsistent $[18,19]$. To select suitable BCTs for our intervention, we applied the APEASE criteria to those we judged most promising (Table 7).

Based on these findings, we prepared a draft of the intervention, i.e. visualized the selected BCTs (Table 7) including a short description and a self-drawn representation of an app on a PowerPoint presentation. We showed the presentation to stem cell transplant patients and caregivers and discussed the various parts' feasibility and usefulness. The participants had the possibility to vote for the different BCTs via a real-time smartphonebased survey (using mentmeter.com) as well as via the accompanying oral group discussion. The patients' feedback indicated that they saw the intervention as both feasible and supportive. With consideration for all of the 
Table 4 Barriers of medication adherence sorted by COM-B

\begin{tabular}{|c|c|c|c|c|}
\hline COM-B & TDF & $\begin{array}{l}\text { What needs to happen for target behavior to } \\
\text { occur? }\end{array}$ & $\begin{array}{l}\text { Information about barriers to } \\
\text { medication adherence }\end{array}$ & $\begin{array}{l}\text { Do factors/barriers need to change } \\
\text { to perform target behavior (based } \\
\text { on contextual analysis)? }\end{array}$ \\
\hline \multirow[t]{2}{*}{$\begin{array}{l}\text { Physical } \\
\text { capability }\end{array}$} & \multirow[t]{2}{*}{ Physical skills } & \multirow[t]{2}{*}{$\begin{array}{l}\text { Being physically able to swallow pills and } \\
\text { remember if already taken }\end{array}$} & \multirow[t]{2}{*}{$\begin{array}{l}\text { Emesis, nausea }[48,49]^{\mathrm{a} b} \\
\text { Poor physical condition }[50] \\
\mathrm{a} \mathrm{b}\end{array}$} & $\begin{array}{l}\text { NO Physical limitations (e.g. } \\
\text { cognitive function) which can't } \\
\text { change }\end{array}$ \\
\hline & & & & $\begin{array}{l}\text { YES Limited physical stamina (e.g. } \\
\text { fatigue, nausea) }\end{array}$ \\
\hline \multirow[t]{4}{*}{$\begin{array}{l}\text { Psychological } \\
\text { capability }\end{array}$} & Knowledge & $\begin{array}{l}\text { Knowledge why intake and timing of } \\
\text { immunosuppressants is important }\end{array}$ & 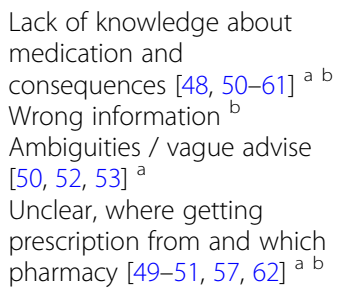 & $\begin{array}{l}\text { YES Lack of knowledge about } \\
\text { importance and consequences of } \\
\text { medication (non-) adherence }\end{array}$ \\
\hline & $\begin{array}{l}\text { Behavioral } \\
\text { regulation }\end{array}$ & $\begin{array}{l}\text { Apply the knowledge of correct medication } \\
\text { intake and timing in every aspect, applying if- } \\
\text { then-rules } \\
\text { Development of coping strategies for barriers }\end{array}$ & $\begin{array}{l}\text { Lack of routine }[51,52,55- \\
57,59,63]^{\text {a }} \\
\text { No sense of autonomy } \\
\text { regarding medication intake } \\
{[51]} \\
\text { History of MNA }[53,64] \\
\text { Longer time since } \\
\text { transplantation }[64] \\
\text { Current major life event } \\
\text { (other priorities) }[49,53] \\
\text { Busy lifestyle }[48,49,51,54 \text {, } \\
57] \\
\text { Alcohol and substance abuse } \\
\text { [51] }\end{array}$ & $\begin{array}{l}\text { YES Lack of procedural knowledge } \\
\text { of medication intake } \\
\text { YES Lack of behavioral regulation } \\
\text { (e.g. self-monitoring) } \\
\text { YES Lack of skills to develop coping } \\
\text { strategies facing barriers }\end{array}$ \\
\hline & $\begin{array}{l}\text { Memory, } \\
\text { attention \& } \\
\text { decision } \\
\text { processes }\end{array}$ & $\begin{array}{l}\text { Notice and remember at prescribed time } \\
\text { during daily life to take medication }\end{array}$ & $\begin{array}{l}\text { Information overload }{ }^{\mathrm{b}} \\
\text { Forgetfulness }[48,49,51,52 \text {, } \\
54-57,65]^{\mathrm{a}} \text {, poor executive } \\
\text { function after transplantation } \\
{[53,65]} \\
\text { Forgetting get a new } \\
\text { prescription on time }[49,50, \\
54,56,57,60]^{\text {a b }}\end{array}$ & $\begin{array}{l}\text { YES Limitations in memory, } \\
\text { concentration, attention \& decision } \\
\text { processes • Lack of awareness / } \\
\text { recognition in daily life }\end{array}$ \\
\hline & $\begin{array}{l}\text { Cognitive and } \\
\text { inter-personal } \\
\text { skills }\end{array}$ & $\begin{array}{l}\text { Development of habit in correct timing and } \\
\text { intake of medication, } \\
\text { Skill to ask for help if needed }\end{array}$ & $\begin{array}{l}\text { Unable to cope with } \\
\text { changed prescription [54] } \\
\text { Lack of psychological skills to } \\
\text { fill pill boxes / prepare } \\
\text { medication correctly [60] }\end{array}$ & $\begin{array}{l}\text { YES Lack of habit-forming, goal- } \\
\text { setting or action-planning skills }\end{array}$ \\
\hline $\begin{array}{l}\text { Physical } \\
\text { opportunity }\end{array}$ & $\begin{array}{l}\text { Environ- } \\
\text { mental } \\
\text { context and } \\
\text { resources }\end{array}$ & $\begin{array}{l}\text { Enough medication available, readily } \\
\text { accessible at opportunities, enough reminder } \\
\text { clues }\end{array}$ & 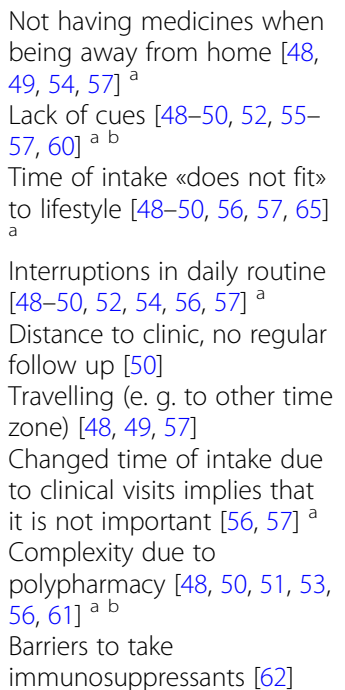 & $\begin{array}{l}\text { YES Lack of facilitation via } \\
\text { accessibility, possibility, easiness, } \\
\text { availability, convenience } \\
\text { YES Lack of facilitation via support } \\
\text { for memory, concentration, attention }\end{array}$ \\
\hline
\end{tabular}


Table 4 Barriers of medication adherence sorted by COM-B (Continued)

\begin{tabular}{|c|c|c|c|c|}
\hline COM-B & TDF & $\begin{array}{l}\text { What needs to happen for target behavior to } \\
\text { occur? }\end{array}$ & $\begin{array}{l}\text { Information about barriers to } \\
\text { medication adherence }\end{array}$ & $\begin{array}{l}\text { Do factors/barriers need to change } \\
\text { to perform target behavior (based } \\
\text { on contextual analysis)? }\end{array}$ \\
\hline \multirow[t]{2}{*}{$\begin{array}{l}\text { Social } \\
\text { opportunity }\end{array}$} & \multirow[t]{2}{*}{$\begin{array}{l}\text { Social } \\
\text { influence }\end{array}$} & \multirow[t]{2}{*}{$\begin{array}{l}\text { Patient participation \& empowerment } \\
\text { regarding an increased awareness about that } \\
\text { medication management is a shared duty of } \\
\text { everyone involved in the care }\end{array}$} & $\begin{array}{l}\text { Lack of family support } \\
\text { (emotional, instrumental) } \\
{[48-53,55-57,59,61,62,65]} \\
\text { a b }\end{array}$ & \multirow{2}{*}{$\begin{array}{l}\text { YES Lack of positive role models } \\
\text { YES Lack of social or peer support } \\
\text { (e.g. patient empowerment / } \\
\text { participation, private or, professional } \\
\text { support) } \\
\text { YES Lack of awareness that } \\
\text { medication intake can be improved } \\
\text { by of everyone involved in the care }\end{array}$} \\
\hline & & & $\begin{array}{l}\text { Lack of social support [ } 48, \\
49,51,53,55,56,59,61,62, \\
65]^{\text {b }} \\
\text { Lack of peer learning (blogs, } \\
\text { internet forum, waiting } \\
\text { room) }[52,53,56,61]^{\text {a }} \\
\text { Incorrect lay knowledge } \\
\text { from peers b } \\
\text { Lack of positive and negative } \\
\text { role models [58] } \\
\text { Lack of individual support } \\
\text { (by nurses, pharmacists) [50, } \\
52,53,56]^{\text {a }} \\
\text { Avoiding taking medication } \\
\text { in public / in front of friends } \\
{[56]} \\
\text { Lack of comparison with } \\
\text { worse ill people [56, 57] } \\
\text { Lack of trusting partnership } \\
\text { with health professionals [50, } \\
53,57,59] \\
\text { Lack of attention from nurses } \\
\text { / health care professionals } \\
{[53,55,62]}\end{array}$ & \\
\hline \multirow[t]{2}{*}{$\begin{array}{l}\text { Automatic } \\
\text { Motivation }\end{array}$} & Emotion & $\begin{array}{l}\text { Positive emotions related to medication } \\
\text { adherence }\end{array}$ & $\begin{array}{l}\text { Feeling overwhelmed [58, } \\
63]^{\text {b }} \\
\text { Burnout / treatment fatigue } \\
{[48,52,55,57] \text {; Depression }} \\
{[51,57,65]} \\
\text { Low quality of life (direction } \\
\text { of association unclear) [51] } \\
\text { Negative emotions / attitude } \\
{[49,53,58,59] \text {; Distress [51, }} \\
54] \\
\text { Desire for independence in } \\
\text { self-management [52, 65] } \\
\text { Nuisance due to repetitive } \\
\text { reminder [57] } \\
\text { Low gratitude toward } \\
\text { medical team/donor [48-52, } \\
54-56,61] \\
\text { Tablet phobia (fear of } \\
\text { swallowing tablets) [53] }\end{array}$ & $\begin{array}{l}\text { YES Lack of coping strategies } \\
\text { YES Low relationship with health } \\
\text { care provider } \\
\text { YES Fear of embarrassment }\end{array}$ \\
\hline & Reinforcement & Strategies for possible problems & $\begin{array}{l}\text { Incompatibility of the } \\
\text { immunosuppressants a b } \\
\text { Side effects }[48-53,65] \text { a b }\end{array}$ & $\begin{array}{l}\text { YES Lack of problem solving } \\
\text { strategies }\end{array}$ \\
\hline \multirow[t]{2}{*}{$\begin{array}{l}\text { Reflective } \\
\text { Motivation }\end{array}$} & Intentions & $\begin{array}{l}\text { Have willingness and a plan on correct intake } \\
\text { and timing }\end{array}$ & $\begin{array}{l}\text { Lack of intention to adhere } \\
{[51]^{\text {a }}} \\
\text { Not interested in learning } \\
\text { about medication before } \\
\text { transplant [60] }\end{array}$ & $\begin{array}{l}\text { YES Insufficient intention } \\
\text { YES Insufficient goals }\end{array}$ \\
\hline & $\begin{array}{l}\text { Beliefs: } \\
\text { consequences }\end{array}$ & $\begin{array}{l}\text { Correct beliefs of resulting consequences of } \\
\text { non-adherence }\end{array}$ & $\begin{array}{l}\text { Beliefs in illness, medication } \\
\text { and side effects }[48,50-61, \\
63]^{\text {a b }} \\
\text { Lack of knowledge about } \\
\text { consequences }[48-55,57,60] \\
\text { a } \\
\text { Consequences of MNA not } \\
\text { clear (health belief) }[51,55]^{a}\end{array}$ & $\begin{array}{l}\text { YES False beliefs about } \\
\text { consequences }\end{array}$ \\
\hline
\end{tabular}


Table 4 Barriers of medication adherence sorted by COM-B (Continued)

\begin{tabular}{|c|c|c|c|c|}
\hline COM-B & TDF & $\begin{array}{l}\text { What needs to happen for target behavior to } \\
\text { occur? }\end{array}$ & $\begin{array}{l}\text { Information about barriers to } \\
\text { medication adherence }\end{array}$ & $\begin{array}{l}\text { Do factors/barriers need to change } \\
\text { to perform target behavior (based } \\
\text { on contextual analysis)? }\end{array}$ \\
\hline & & & $\begin{array}{l}\text { Blood test did not capture } \\
\text { MNA [56] } \\
\text { Establishing a personal } \\
\text { leeway of time [49] } \\
\text { Defining acceptable risks [52] } \\
\text { Trivialization and denial [52, } \\
56,57]^{\text {a }}\end{array}$ & \\
\hline & $\begin{array}{l}\text { Beliefs: } \\
\text { capabilities }\end{array}$ & $\begin{array}{l}\text { Correct beliefs of capability in medication } \\
\text { management }\end{array}$ & $\begin{array}{l}\text { No confidence in self- } \\
\text { management (mastery) [50- } \\
53,58] \\
\text { Lack of problem solving } \\
\text { competence and self-efficacy } \\
{[50-52]^{\text {a }}}\end{array}$ & $\begin{array}{l}\text { YES False beliefs about own } \\
\text { capabilities (e.g. self-efficacy) }\end{array}$ \\
\hline & Goals & $\begin{array}{l}\text { Correct beliefs of own responsibility for } \\
\text { outcomes }\end{array}$ & $\begin{array}{l}\text { Lack of motivation to } \\
\text { convalescence }[55,58]]^{\text {b }} \\
\text { Making medications a low } \\
\text { priority }[57]\end{array}$ & $\begin{array}{l}\text { YES False beliefs in own } \\
\text { responsibility for wanted outcomes }\end{array}$ \\
\hline & Optimism & $\begin{array}{l}\text { Confidence that desired goals will be } \\
\text { achieved }\end{array}$ & Maladaptive coping [65] & $\begin{array}{l}\text { YES Lack of adaptive coping } \\
\text { strategies (to reduce stress) }\end{array}$ \\
\hline & $\begin{array}{l}\text { Role and } \\
\text { identity }\end{array}$ & $\begin{array}{l}\text { Compatible set of behaviors with professional } \\
\text { identity }\end{array}$ & $\begin{array}{l}\text { Evading patient hood [52] } \\
\text { Seeing self as a victim [52] }\end{array}$ & $\begin{array}{l}\text { YES Behaviors incompatible with } \\
\text { professional identity }\end{array}$ \\
\hline
\end{tabular}

MNA Medication non-adherence

a: 10 individual interviews with alloSCT patients conducted by our research team, $2017 ;^{\text {b }}: 3$ focus groups with alloSCT health care providers conducted by our research team, 2017

information thus far compiled, we selected 24 patientlevel BCTs, including goal setting, action planning and self-monitoring of behavior. All selected BCTs are listed in Table 8.

\section{$B C W$ step 8: identify mode of delivery}

The eighth and last of the BCW's core processes is to identify the most suitable mode of delivery for the selected BCTs. This determines how the intervention should be delivered to the alloSCT patients and their caregivers, i.e., the end-users. A wide variety of delivery modes can support an intervention's implementation and effectiveness, ranging face-to-face individual or group sessions to mobile phone apps [34]. The optimal delivery mode was determined using information generated from the previous steps, the contextual analysis and end-user feedback [34].

Results. Our contextual analysis [36] showed that alloSCT patients were open to technological assistance but emphasized that eHealth support should not replace personal contact with the health care team. Accordingly, of all available possibilities for face-to-face (delivered by the CC) or distance (technology assisted) interventions, we selected the most suitable mode of delivery for each of our intervention's BCTs (Table 8).

The resulting draft of the SMILe Care Model Prototype integrates a CC (an APN with specialization in oncology) and the SMILeApp ("prototype" means the whole care model, not only the app component). The BCTs to support medication adherence will be delivered to the patients during two face-to-face visits with the CC, e.g. demonstration how to perform the behavior (e.g. prepare the medication) or habit formation. Depending on the patient's condition, the care protocols allow for a step-up approach including more intensive tailored interventions. Between face-to-face visits, we planned to support patients with several BCTs delivered by the SMILeApp, e.g., selfmonitoring of the behavior (Table 8).

The intervention draft was discussed with alloSCT patients and caregivers to prioritize functionalities. This process will later guide the order of the software and intervention development. Patients agreed unanimously that the SMILeApp should ideally include a current and complete medication plan that could be automatically updated after every change to the medication regimen. Patients considered this as a feasible way to confirm their medication intake after every intake. Most participants also considered it acceptable and helpful to receive a reminder for data entry once a day at a user-defined time, with graphical feedback for entered values.

All findings arising from steps 4 to 8 are presented in Table 8 which also indicates which COM-B and TDF domains are influenced by each intervention function and policy category, as well as the resulting BCTs and modes of delivery.

\section{Additional stage 4: SMILe care model prototype development}

The translation of the SMILe intervention into an eHealth solution will enable delivery of important BCTs, e.g., self-monitoring and feedback on target behaviors to 
Table 5 Applying the APEASE criteria to select useful intervention functions

\begin{tabular}{|c|c|c|c|c|c|c|c|c|}
\hline $\begin{array}{l}\text { Factors/barriers that need to } \\
\text { change to perform target } \\
\text { behavior (step 4) }\end{array}$ & $\begin{array}{l}\text { Intervention } \\
\text { function }\end{array}$ & Affordability & Practicability & $\begin{array}{l}\text { (Cost-) } \\
\text { Effectiveness }\end{array}$ & Acceptability & $\begin{array}{l}\text { Side- } \\
\text { effects/ } \\
\text { Safety }\end{array}$ & Equity & $\begin{array}{l}\text { Does the intervention } \\
\text { function meet the } \\
\text { APEASE criteria, } \\
\text { comments why yes/ } \\
\text { no? }\end{array}$ \\
\hline $\begin{array}{l}\text { PhC: Lack of knowledge; lack of } \\
\text { awareness / recognition in daily } \\
\text { life } \\
\text { ReM: False beliefs about } \\
\text { consequences and own } \\
\text { responsibility for intended } \\
\text { outcomes }\end{array}$ & Education & ++ & ++ & + & ++ & + & + & $\begin{array}{l}\text { YES - provision of } \\
\text { knowledge }\end{array}$ \\
\hline \multirow{3}{*}{$\begin{array}{l}\text { SoO: Lack of awareness that } \\
\text { medication intake can be } \\
\text { improved by everyone involved } \\
\text { in care } \\
\text { AuM: Poor relationship with } \\
\text { health care provider; fear of } \\
\text { embarrassment } \\
\text { ReM: } \text { False beliefs about own } \\
\text { capabilities; behaviors } \\
\text { incompatible with identity }\end{array}$} & Persuasion & + & + & + & ++ & ++ & ++ & $\begin{array}{l}\text { YES - foster positive } \\
\text { feelings, motivation; } \\
\text { beliefs about capability, } \\
\text { goals (self-efficacy) }\end{array}$ \\
\hline & Incentivization & - & \pm & - & \pm & + & \pm & $\begin{array}{l}\text { NO - not effective and } \\
\text { not affordable }\end{array}$ \\
\hline & Coercion & & & & & & & NO - Not acceptable \\
\hline $\begin{array}{l}\text { PsC: Lack of knowledge of drug } \\
\text { intake procedure; lack of skills to } \\
\text { develop coping strategies; } \\
\text { limitations in memory \& } \\
\text { decision processes }\end{array}$ & Training & + & + & + & + & ++ & ++ & $\begin{array}{l}\text { YES - provision of } \\
\text { training to prepare } \\
\text { medication / use pill } \\
\text { boxes / use reminders } \\
\text { / self-monitoring }\end{array}$ \\
\hline
\end{tabular}

PhO: Lack of facilitation via

support for memory,

concentration, attention

SoO: Lack of social or peer support

AuM: Lack of coping strategies ReM: Lack of adaptive coping strategies

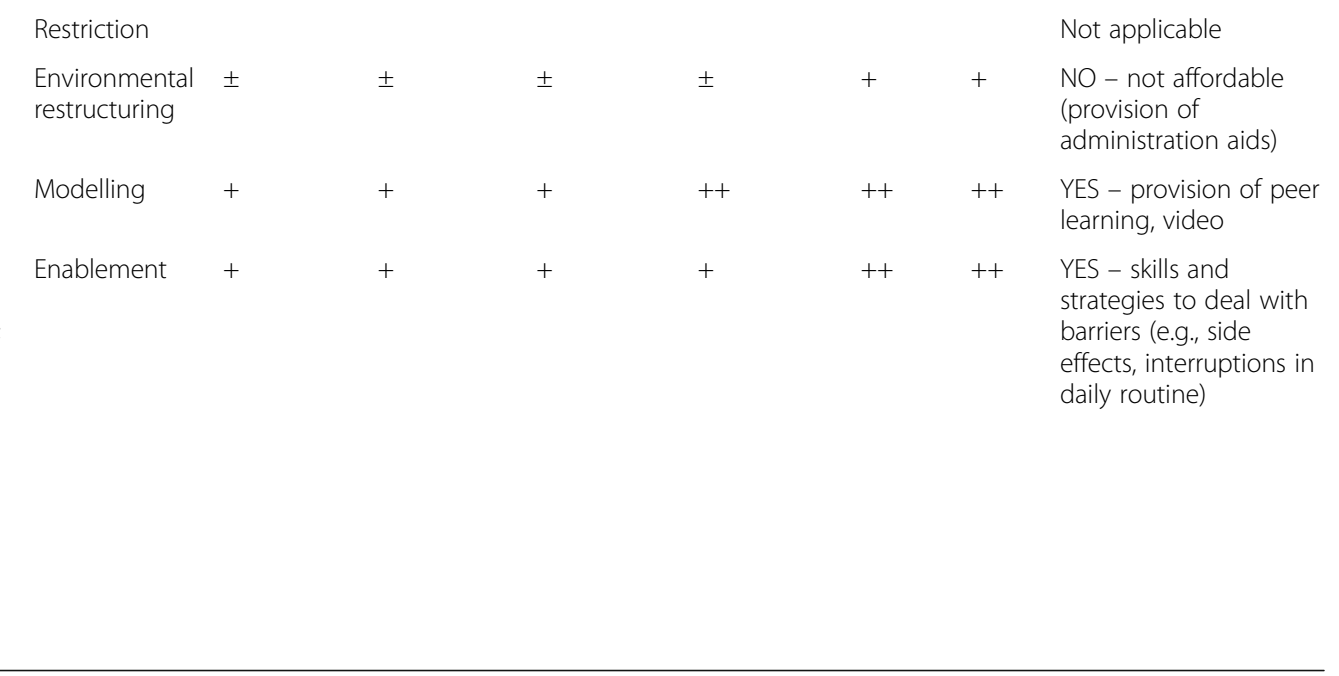

SoO: Lack of positive role models

PhC: Limited physical stamina PsC: Lack of habit-forming, goal-setting or action-planning; lack of behavioral regulation PhO: Lack of facilitation via accessibility, easiness, availability, convenience SoO: Lack of social or peer support

AuM: Lack of problem-solving strategies

ReM: Insufficient intention and goals (++ very promising) (+ promising) ( \pm not promising but worth considering) (- unacceptable)

patients anywhere (e.g., in their homes or workplaces) at any time [2, 3]. Therefore, after working through the three stages and eight core steps of the $\mathrm{BCW}$, we developed a fourth stage - SMILe Care Model Prototype Development - which includes two steps, both of which are based on agile software development techniques (Fig. 
Table 6 Applying the APEASE criteria to select useful policy categories based on contextual analysis

\begin{tabular}{|c|c|c|c|c|c|c|c|c|}
\hline $\begin{array}{l}\text { Intervention } \\
\text { function }\end{array}$ & Policy category & Affordability & Practicability & $\begin{array}{l}\text { (Cost- } \\
\text { )Effectiveness }\end{array}$ & Acceptability & $\begin{array}{l}\text { (Side- } \\
\text { effects) } \\
\text { / Safety }\end{array}$ & Equity & $\begin{array}{l}\text { Does the intervention function } \\
\text { meet the APEASE criteria, } \\
\text { comments why yes/no? }\end{array}$ \\
\hline & $\begin{array}{l}\text { Communication/ } \\
\text { marketing }\end{array}$ & \pm & + & \pm & ++ & + & + & $\begin{array}{l}\text { NO - not affordable, not suitable } \\
\text { in our situation }\end{array}$ \\
\hline & Guidelines & - & \pm & \pm & + & ++ & ++ & $\begin{array}{l}\mathrm{NO} \text { - national level } \rightarrow \text { not } \\
\text { affordable in our situation }\end{array}$ \\
\hline & Fiscal measures & - & \pm & \pm & \pm & + & ++ & $\begin{array}{l}\text { NO - not affordable in our } \\
\text { situation: } \\
\text { Germany: Financial burden due to } \\
\text { travelling to Tx center, drug usually } \\
\text { paid } \\
\text { Switzerland: Patients pay } \\
\text { Deductible }+10 \%\end{array}$ \\
\hline \multirow[t]{3}{*}{$\begin{array}{l}\text { Education, } \\
\text { Persuasion, } \\
\text { Training, } \\
\text { Modeling, } \\
\text { Enablement }\end{array}$} & Regulation & + & + & + & + & + & ++ & $\begin{array}{l}\text { YES - center level } \rightarrow \text { regulation } \\
\text { about what, how \& how long } \\
\text { contact with health care provider } \\
\text { can continue }\end{array}$ \\
\hline & Legislation & & & & & & & $\begin{array}{l}\text { NO - not relevant, not practicable } \\
\text { in our setting }\end{array}$ \\
\hline & $\begin{array}{l}\text { Environmental/ } \\
\text { social planning }\end{array}$ & \pm & \pm & + & + & + & ++ & $\begin{array}{l}\text { NO }- \text { WLAN access } \rightarrow \text { not } \\
\text { affordable in our situation }\end{array}$ \\
\hline $\begin{array}{l}\text { Education, } \\
\text { Persuasion, } \\
\text { Training, } \\
\text { Modelling, } \\
\text { Enablement }\end{array}$ & Service provision & ++ & ++ & + & ++ & ++ & ++ & $\begin{array}{l}\text { YES - e.g., support \& checks via } \\
\text { phone / improvement of } \\
\text { performance at visits, introduction } \\
\text { of a CC }\end{array}$ \\
\hline
\end{tabular}

CC Care-coordinator

(++ very promising) (+ promising) ( \pm not promising but worth considering) (- unacceptable)

2). Developed to facilitate early integration within the target setting, a highly iterative methodology and the inclusion of end-user feedback in the development process ensures the software's usefulness to patients, caregivers and clinicians alike [35].

\section{Additional step 9: prepare digitalization}

To prepare for digitization, step 9 deals with the formulation of user stories [35]. User stories are a means to capture requirements that should be delivered by a software product. This makes their stories a valuable basis for discussion between software developers and intervention developers [35]. User stories are an opportunity for researchers to provide key information to software developers about important functionalities that are needed in the app. They will not directly appear in the app, only by means of the functionality implemented. The goal of user stories it to provide key information between researchers and software developers and, thus, are not communicated to patients.

While user stories can be structured in numerous ways, the role-feature-reason format is most popular [35]. This begins with a structured sentence (As a ... (person, e.g., allo-SCT patient), I want ... (action, e.g., keep track of my medication intake), so that ... (expected outcome, e.g., I know if I take my medication correctly)) describing a possible software function. Structuring the essential elements in a standard form eases the translation of the corresponding BCTs into the SMILeApp [35]. The concrete realization of a user story is decided in close consultation with the software development team.

Results. To ensure the translation of the most effective BCTs into our eHealth component, we wrote 17 user stories to the software developers in the role-featurereason format based on the previous findings (Table 9). Following the principles of agile software development, continuous end-user testing and user-centered design, the needs and priorities these stories suggest will help the designers first to develop mock-ups of new modules for early user testing, then to ensure that later versions of the app meet user needs as fully as possible [35]. A separate paper will describe the development of the technology aspects in detail (in preparation).

\section{Additional step 10: prepare CC intervention}

Based on the previous steps of the $\mathrm{BCW}$, we wrote a comprehensive intervention protocol for the intervention's face-to-face CC visits. This protocol describes every face-to-face visit in terms of when, by whom and to whom it should be delivered (patient \pm caregiver(s)), as well as which BCTs should be applied in what order 


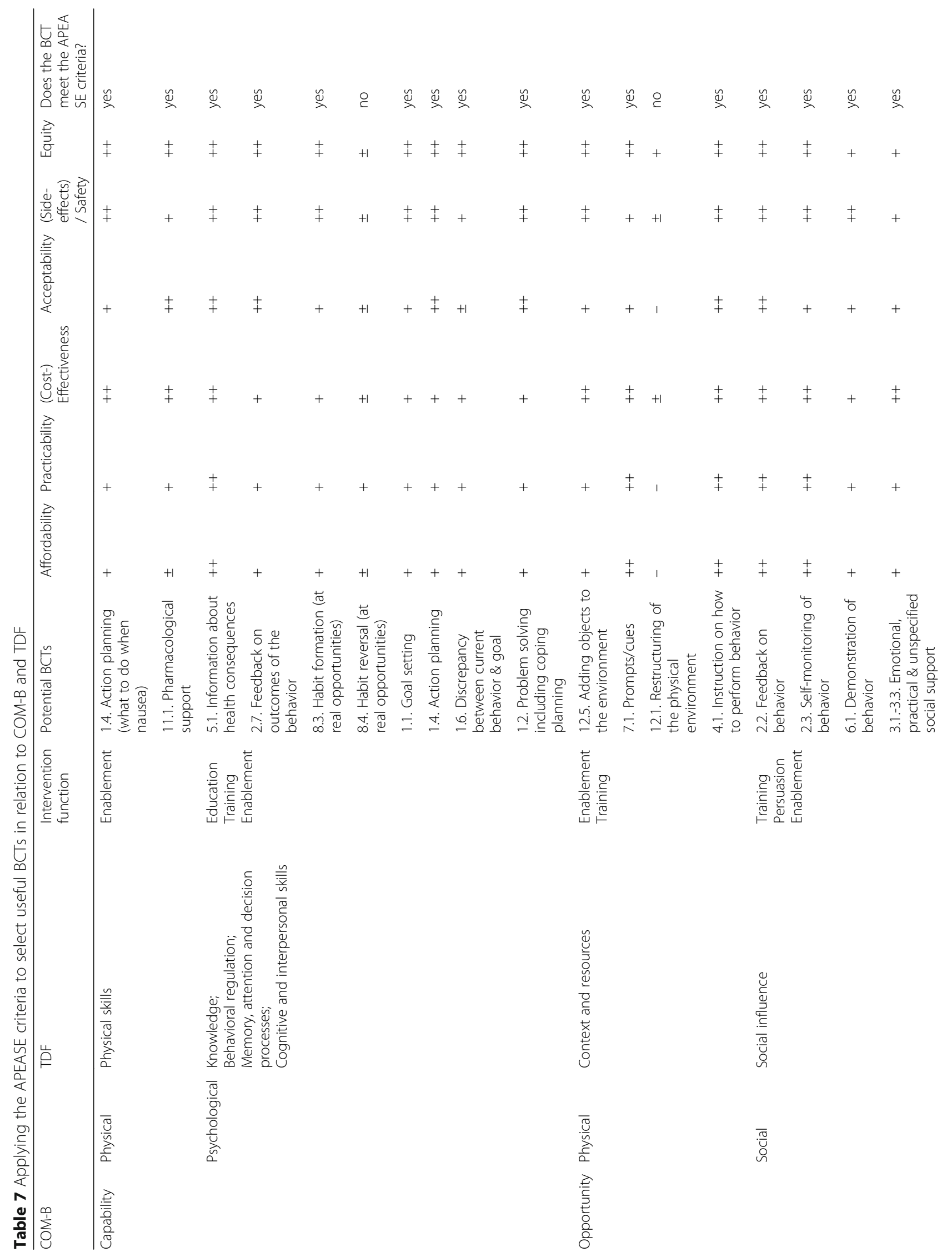




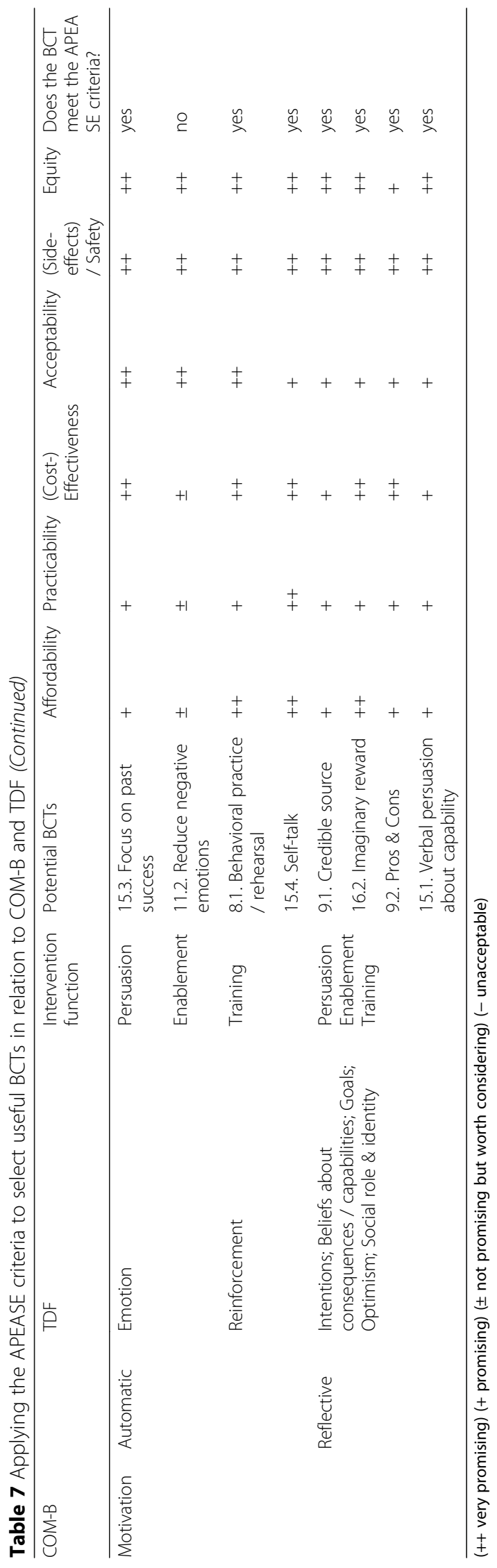


Table 8 The selected intervention functions, policy categories, BCT and delivery mode relating to COM-B and TDF

\begin{tabular}{|c|c|c|c|c|c|c|}
\hline COM-B & & TDF & $\begin{array}{l}\text { Intervention } \\
\text { function }\end{array}$ & $\begin{array}{l}\text { Policy } \\
\text { category }\end{array}$ & BCT & Mode of delivery \\
\hline \multirow[t]{2}{*}{ Capability } & Physical & Physical skills & Enablement & $\begin{array}{l}\text { Service } \\
\text { provision, } \\
\text { Regulation }\end{array}$ & $\begin{array}{l}\text { 1.4. Action planning } \\
\text { 11.1. Pharmacological } \\
\text { support }\end{array}$ & $\begin{array}{l}\text { Face-to-face, Phone helpline, info on app } \\
\text { Mobile phone App (written information)/ } \\
\text { Phone helpline with linkage to TX-Center }\end{array}$ \\
\hline & Psychological & $\begin{array}{l}\text { Knowledge } \\
\text { Behavioral } \\
\text { regulation } \\
\text { Memory, attention } \\
\text { \& decision process } \\
\text { Cognitive \& } \\
\text { interpersonal skill }\end{array}$ & $\begin{array}{l}\text { Education } \\
\text { Training } \\
\text { Enablement }\end{array}$ & $\begin{array}{l}\text { Service } \\
\text { provision, } \\
\text { Regulation }\end{array}$ & $\begin{array}{l}\text { 5.1. Information about health } \\
\text { consequences } \\
\text { 2.7. Feedback on outcomes } \\
\text { of the behavior } \\
\text { 8.3. Habit formation (at real } \\
\text { opportunities) } \\
\text { 1.1. Goal setting } \\
\text { 1.6. Discrepancy between } \\
\text { behavior \& goal } \\
\text { 1.2. Problem solving (incl. } \\
\text { Coping planning) }\end{array}$ & $\begin{array}{l}\text { Face-to-face, App (written, video) } \\
\text { Face-to-face } \\
\text { Face-to-face } \\
\text { Face-to-face, App (goal-reminder) } \\
\text { Face-to-face, Phone helpline } \\
\text { Face-to-face, Phone helpline }\end{array}$ \\
\hline \multirow[t]{2}{*}{ Opportunity } & Physical & $\begin{array}{l}\text { Context \& } \\
\text { resources }\end{array}$ & $\begin{array}{l}\text { Training } \\
\text { Enablement }\end{array}$ & $\begin{array}{l}\text { Service } \\
\text { provision, } \\
\text { Regulation }\end{array}$ & $\begin{array}{l}\text { 7.1. Prompts/cues } \\
\text { 4.1. Instruction on how to } \\
\text { perform behavior } \\
\text { 12.5. Adding objects to the } \\
\text { environment }\end{array}$ & $\begin{array}{l}\text { App (reminder, information), Face-to-face } \\
\text { Face-to-face, App (video, written info) } \\
\text { App itself, information on App, } \\
\text { Face-to-face }\end{array}$ \\
\hline & Social & Social influences & $\begin{array}{l}\text { Training } \\
\text { Modelling } \\
\text { Persuasion } \\
\text { Enablement }\end{array}$ & $\begin{array}{l}\text { Service } \\
\text { provision, } \\
\text { Regulation }\end{array}$ & $\begin{array}{l}\text { 2.2. Feedback on behavior } \\
\text { 2.3. Self-monitoring of } \\
\text { behavior } \\
\text { 6.1. Demonstration of } \\
\text { behavior } \\
\text { 3.1.-3.3. Emotional, practical } \\
\text { and unspecified social } \\
\text { support }\end{array}$ & $\begin{array}{l}\text { Face-to-face, App (by mobile phone text) } \\
\text { App questionnaire, Face-to-face } \\
\text { Face-to-face, App (video) } \\
\text { Face-to-face }\end{array}$ \\
\hline \multirow[t]{2}{*}{ Motivation } & Automatic & $\begin{array}{l}\text { Emotion } \\
\text { Reinforcement }\end{array}$ & $\begin{array}{l}\text { Persuasion } \\
\text { Enablement } \\
\text { Training }\end{array}$ & $\begin{array}{l}\text { Service } \\
\text { provision, } \\
\text { Regulation }\end{array}$ & $\begin{array}{l}\text { 15.3. Focus on past success } \\
\text { 8.1. Behavioral practice / } \\
\text { rehearsal } \\
\text { 15.4. Self-talk }\end{array}$ & $\begin{array}{l}\text { Face-to-face, Phone helpline } \\
\text { Face-to-face } \\
\text { Face-to-face, App (included in } \\
\text { reminder) }\end{array}$ \\
\hline & Reflective & $\begin{array}{l}\text { Intentions } \\
\text { Beliefs } \\
\text { Goals } \\
\text { Optimism } \\
\text { Role \& identity }\end{array}$ & $\begin{array}{l}\text { Education } \\
\text { Persuasion } \\
\text { Enablement } \\
\text { Training }\end{array}$ & $\begin{array}{l}\text { Service } \\
\text { provision, } \\
\text { Regulation }\end{array}$ & $\begin{array}{l}\text { 9.1. Credible source } \\
\text { 16.2. Imaginary reward } \\
\text { 9.2. Pros \& Cons } \\
\text { 15.1. Verbal persuasion about } \\
\text { capability }\end{array}$ & $\begin{array}{l}\text { App (video) } \\
\text { Face-to-face, Phone helpline } \\
\text { Face-to-face } \\
\text { Face-to-face, Phone helpline }\end{array}$ \\
\hline
\end{tabular}

and which methods should be used. To ensure standardized, reproducible intervention delivery, descriptions and terminology adhered closely to the BCT taxonomy. The intervention protocol was written in alignment with implementation science lens, meaning, that the intervention has been designed using the previously described implementation science methods (e.g. contextual analysis, stakeholder involvement) in such a way that it can be implemented and used in real world settings in the future.

Results. The complete protocol consisted of 70 pages for all modules with the detailed description of the content to be used for education, training and supervision of the CC. We also wrote a short version with 49 pages for all modules to be used by the $\mathrm{CC}$ during the face-toface visits as a checklist.

We initially planned to implement and test the whole medication adherence module via both, the CC (face-to- face visits) and the SMILeApp in an RCT. However, due to lack of time resources, the current version of the SMILeApp does not include medication adherence support yet. For this reason, in the current RCT, which started at the beginning of 2020 at the University Hospital of Freiburg im Breisgau (FiB), only the faceto-face visits of the medication adherence module are implemented and tested. This downsized version of the care model is called the SMILe-V1 Care Model Prototype-FiB as it is tested at the University Hospital of FiB. Our prepared user stories will be prioritized and translated into the next version of the SMILeApp to be implemented and evaluated in combination with the CC's face-to-face visits in an RCT at the University Hospital of Basel (USB). This full version of the care model will be called the SMILeV2 Care Model Prototype-USB. 
Table 9 User stories according to the BCT

\begin{tabular}{ll}
\hline BCT & Description \\
\hline $\begin{array}{l}\text { 1.1. Goal setting } \\
\text { (behavior) }\end{array}$ & $\begin{array}{l}\text { Goals will be set together with patient to take the medication } \\
\text { correctly with a deviation }<2 \mathrm{~h} .\end{array}$ \\
& \\
$\begin{array}{l}\text { 1.4. Actionplanning } \\
\text { Patients will be encouraged to prepare a plan how to deal with } \\
\text { barriers (e.g. have a travel set of their medication prepared and to } \\
\text { take it with them when leaving home) }\end{array}$
\end{tabular}

2.3. Self-monitoring Instructions on checking the medication plan daily and of behavior confirming medication intake daily. Instructions on how to control this monitoring on their own.

2.2. Feedback on Give patients feedback about on how many days they correctly behavior managed their medication intake. Give patients feedback about on how many days their time of medication intake was correct.

4.1. Instruction on Training on how to read the medication plan and prepare their how to perform medication correctly accordingly.

behavior

5.1. Information about health consequences

Oral and written information about effects, side-effects of medication.

Oral and written information about consequences of non -/adherence.

6.1. Demonstration Demonstrate how to read medication plan and prepare the of behavior medication.

7.1. Electronic prompts/cues

1.2. Problem solving

Storage of medication in clear visible places (e.g., next to the coffee machine, TV), to prompt medication intake.

Use of an electronic reminder (for medication intake, goal) on the App with a preferred signal (e.g., alarm tone, picture).

Identify together with patient what could be barriers to take the medication correctly, and discuss ways in which they could help overcome them.

Learn about most common side-effects and fitting interventions to take.

1.6. Discrepancy Point out if the recorded number / time of medication intake between behavior does not fit to the goal set.

\& goal

7.1. Electronic prompts/cues

Medication plan in app
User stories

As a patient I want to be reminded of my set goals (which were set during visit) on a self-determined interval (e.g. daily / once a week) so that I am aware of my goal and know what to target at.

As a patient I want to have reliable information how to plan my expected actions (e.g. leaving home, travelling, eating outside) so that I do not forget the necessary preparations.

As a patient I want to self-monitor whether I take my medication as prescribed so that I know whether I take the drugs correctly.

As a patient I want to get feedback whether I take my medication sufficiently as prescribed so that I can be sure that I take the medication correctly

As a patient I want to know how to prepare my medication so that I can do it on my own correctly

As a patient I want to find information on what my medication is for and will happen, if I do (not) take it as prescribed (incl. wrong time) so that I know the importance of doing it correctly.

As a patient I want to get explained how to use the electronic medication plan so I can check when I have forgotten.

As a patient I want to get a reminder when I need to take my medication and don't forget to take it.

As a patient I want to customize my app (e.g. different tones, signals, colours, pictures) so that I connect medication intake with a positive feeling.

As a patient I want to have the opportunity to call a qualified health care provider if there are unexpected barriers (which were not discussed face-to-face) so that I get support in challenging situations.

As a patient I want to be able to signal the CC that she/he should call back when she/he has time so that I get help without disturbing the CC in an unsuitable situation.

As a patient I want to get a signal if the recorded number / time of medication intake does not fit to the goal set so that I realize that I have to change my behavior.

As a patient I want to have my medication plan in the app so that I can look up my medication on my smartphone. As a patient I want to be able to update the medication plan in the app when the prescription of physician changes so that I have a current medication plan on my smartphone.

As a patient I want to learn from a qualified health care provider or a peer why the medication intake and timing is so important so that I am aware of its importance.

As a patient I want to get a motivational feedback that I can successfully perform the behavior so that I feel capable to manage the correct medication intake.

As a patient I want to be able to record occasions with correct medication intake in the App so that I feel confident to be successful again.

\section{Discussion}

To our knowledge, this paper is the first to provide an example of how to develop a theory-based medication adherence intervention for translation into an eHealth system. Our work, embedded in an implementation science approach, applied the principles recommended by the BCW, and particularly of the COM-B model at its center. This framework's major strengths are its 
multilevel perspective and the explicit inclusion of emotional factors, which tend to be less prominent or absent in other behavioral theories [34]. While other authors have used the BCW to develop eHealth facilitated behavior change interventions, none have described their development process (including the translation of an intervention into an eHealth application) in this detail, and many have not included patients or incorporated them only at a late stage of intervention development $[37,38,67]$.

Worldwide, health care services and providers are moving in the direction of digitization [68]. The number of newly released health related apps is currently growing by over 200 per day: between 2015 and 2018, the number available in the top app stores almost doubled to nearly $320^{\prime} 000$ [24]. Many aim to support patients in medication adherence [22] and some have showed promising results in RCTs in various populations $[14,16,17]$. In the development of an eHealth facilitated intervention, it is crucial to rely on the theory, consider the most recent evidence, integrate information on the context where the intervention or app will be applied and involve all major stakeholders - especially patients - from the earliest stages [24, 28, 69, 70]. And while theory-based interventions are most likely to improve medication adherence $[28,69]$, extremely few apps are developed following these recommendations.

To exacerbate the problem, producers typically supply limited or no information on the processes either of their apps' implementation or of their results in real-life settings $[16,29]$. This paper addresses these shortcomings using the example of the SMILe integrated care model's medication adherence intervention module. Unlike many existing eHealth tools, our intervention development incorporated extensive end-user involvement (i.e., of patients, caregivers, clinicians), enhancing its relevance regarding implementation in real-life settings. Our goal was not simple to develop the best possible intervention to provide the basis for digitalization and medication adherence interventional components, but also to maximize the likelihood of its successful implementation and sustainability in daily clinical alloSCT follow-up care.

This paper also presents a first step towards bridging the gap between trial and real-world contexts in the development and implementation of a medication adherence module: it describes how to combine empirical evidence with contextual data [36] as the foundation of an eHealth facilitated intervention. The involvement of all relevant stakeholders was indispensible for this module's durable implementation into clinical practice [27, 34].

In addition, by developing user stories based on enduser needs and feedback, we combined the central principles of Implementation Science - sensitivity to context, building on an existing evidence base, extensive stakeholder involvement - with the principles of agile software development and user-centered design [35, 70]. With the result - an iterative, incremental, usercentered approach with early connection to the target context - we intend to speed the translation of cuttingedge research findings into routine use not only by clinicians but also by the target (alloSCT patient) population $[24,70]$. By involving the various stakeholder groups at each appropriate stage, we ensured that the intervention would fit the needs of end-users and be feasible for sustainable use in clinical practice. This fact alone sets our eHealth tools apart from others, the vast majority of which are typically developed by software designers with little or no input from health care research teams [24].

The BCW is a relatively novel multilevel behavioral framework that both explains and provides a stable framework for intervention development. Building for our work upon the evaluation of correlates/determinants of medication adherence intervention development, not only does it include cognitive patient-level factors, it also explicitly includes emotional factors that are not prominent in currently prevalent health behavior models, e.g., the Integrated Model of Behavioral prediction [34, 71].

By assisting in the selection of appropriate behavior change interventions [34], the $\mathrm{BCW}$ provides invaluable guidance for intervention development. And by drawing from diverse information sources it allows the combination of quantitative and qualitative evidence, the results of contextual analysis and stakeholder involvement [34], and the researchers' clinical expertise. The full range of these sources informed our intervention development.

Integral to the $\mathrm{BCW}$, the $\mathrm{BCT}$ taxonomy [72] provides standardized language to label even the smallest units of behavioral change interventions. In addition to enhancing the reporting and communication of complex interventions' content and enhancing their replicability, this level of standardization facilitates meta-analysis, especially as it is used to detect the best-performing intervention components.

Although the BCW is arguably an excellent foundation for intervention development, we added one stage to it at the end of our development process. To speed and simplify translation of the medication adherence module into an eHealth application, we recommend and describe the formulation of user stories as a bridge between intervention developers and software developers. Congruent with the BCW's aims, agile software development focuses both on stakeholder involvement and on the adaption of the software according to the needs of its end-users [35].

One notable challenge regarding the use of the $\mathrm{BCW}$ is that, even while its developers provide a step-by-step process for intervention development, they tend to provide only brief descriptions of the links between those steps, which can make following their recommendations rather challenging especially for those who use the 
framework for the first time. Regarding applying COM$\mathrm{B}$ to our specific research question, we faced the issue that there is very few evidence regarding medication adherence in alloSCT. Therefore, we had to expand our searches on similar populations. Additionally, following the steps left us with more potential options (i.e., BCTs) than could possibly be realized from a resource and logistical perspective. Future refinement of the $\mathrm{BCW}$ could help to overcome this challenge by providing more guidance on which of the possible BCTs would be most appropriate. In our example we based the selection and reduction to the most important and promising options on the feedback of the stakeholders to promote feasible implementation: We applied the APEASE criteria to each possible BCT and discussed which possible app functionalities would specifically help stem cell transplant patients and their caregivers with decision-making and prioritization. This approach ensured that the intervention would fit the needs and preferences of the end-users.

Application of theory is facilitated by examples. While our example focuses directly on the development of behavioral intervention and eHealth app, it and its underlying theory can also be applied to the adaptation of existing interventions and apps to new contexts. Nevertheless, a strong knowledge of the theory is crucial and needs to be firmly in place before starting the development process. To bring all the needed competencies and perspectives to the table, an interdisciplinary team and stakeholder involvement are essential.

Our international multidisciplinary research team consists of 31 researchers and clinicians, two of whom were members of the $\mathrm{BCW}$ development team for the medication adherence module. Several of our researchers also went to London to follow summer courses offered by the group led by Susan Michie, who developed the $\mathrm{BCW}$. In all, development of the SMILe intervention modules required an investment of more than 1 year. Therefore, we advise other researchers that, to prepare adequately for this task, they should combine readings of papers and books with formal training. Another valuable option would be to collaborate with more experienced researchers to peer support this process.

It is still unknown, whether a theory-based developed intervention module such as ours is able to improve medication adherence in alloSCT. In addition, it is unclear whether an analogue or digital intervention, or even the combination of both is the most successful which needs further investigation. Our study's results will support agile technology development of the SMILe medication adherence module as part of the SMILe integrated care model. The SMILe-V1 Care Model Prototype-FiB (without medication adherence in the SMILeApp) and SMILe-V2 Care Model Prototype-USB (with medication adherence in the SMILeApp) will subsequently be implemented and tested as part of an implementation science study to address these knowledge gaps (https://smile.nursing.unibas.ch/). Once the SMILe Care Model Prototype has proven its effectiveness, it can be sustainably implemented in clinical practice as it was developed under consideration of implementation science aspects (e.g. feasibility and acceptability).

\section{Limitations}

Our development of the eHealth component of our care model was subject to certain restrictions. For example, as contextual factors such as data security legislation are very strict in Switzerland and the EU, certain proposed app functions could not be included. Even if qualitative literature and the involved patients had certain priorities regarding the functionality of the SMILeApp, other factors such as the legal framework could force different sequences of the app development process. However, the whole medication adherence module is more than just the eHealth part, why a first testing of the intervention is still possible.

\section{Conclusion}

As intended, this paper describes the theory-driven development, based on the $\mathrm{BCW}$, of a medication adherence intervention module as part of the SMILe integrated care model for alloSCT patients, which includes a patient-centered app and introduces one new care team role: a CC. The associated study's results are currently in use for agile technology development, employing a user-centered design approach, of the innovative SMILe integrated care model's medication adherence module. The overall care model will be implemented and tested as part of a planned implementation science study. While the methods described are applied to this particular medication adherence intervention, as they follow BCW recommendations, they can be adapted to the development of a wide range of behaviortargeted eHealth applications.

\section{Supplementary information}

Supplementary information accompanies this paper at https://doi.org/10. 1186/s12913-020-05636-1.

\section{Additional file 1.}

\section{Abbreviations}

AlloSCT: Allogeneic stem cell transplantation; BCT: Behavior Change Techniques; BCW: Behavior Change Wheel; CC: Care-coordinator; COMB: Capability-Opportunity-Motivation-Behavior Model; CReDECI 2: Criteria for Reporting the Development and Evaluation of Complex Interventions in healthcare: revised guideline; EM: Electronic monitoring; EMERGE: ESPACOMP Medication Adherence Reporting Guideline; ESPACOMP: European Society for Patient Adherence, Compliance, and Persistence; FiB: Freiburg im Breisgau; GvHD: Graft-versus-Host Disease; MNA: Medication non-adherence; 
RCT: Randomized controlled trial; TDF: Theoretical Domains Framework; TIDieR: Template for Intervention Description and Replication; USB: University Hospital of Basel

\section{Acknowledgements}

We acknowledge the SMILe study team, especially Sonja Beckmann, Juliane Mielke and Anja Schmid of the Institute of Nursing Science, University of Basel, Switzerland; Nathalie Duerinckx of the Academic Centre for Nursing and Midwifery, University of Leuven, Belgium, as well as Phillip Heidegger, Margarita Fürmann, Daniela Neupert, Dennis Rockstein, Viktor Werlitz, Michael Fürmann, Tobias Schulz, Marina Lemcke and Vanessa Schumacher of the University of Applied Sciences, Augsburg, Germany. On the clinical side, we acknowledge Robert Zeiser, Monika Engelhardt, Monika Hasemann and Klaus Kaier from the University Medical Center Freiburg, Germany, as well as Sabine Gerull, Jakob Passweg, Anja Ulrich, Florian Grossmann, Dora Bolliger, Sigrun Reitwiessner, Sabine Degen, Sandra Schönfeld, Yuliya Senft, and Birgit Maier from the University Hospital of Basel, Switzerland. We also thank Chris Shultis for the the editing of this paper.

\section{Reporting guideline checklist}

As we were developing an intervention we followed the Criteria for Reporting the Development and Evaluation of Complex Interventions in healthcare: revised guideline (CReDECI 2) [73], the Template for Intervention Description and Replication (TIDieR) where applicable and to the extent appropriate to the objectives of this paper [74]; and because the intervention concerns medication adherence we also followed the ESPACOMP Medication Adherence Reporting Guideline (EMERGE) [4] where applicable.

\section{Authors' contributions}

The study was designed by SDG (corresponding author: sabina. degeest@unibas.ch) and JR. Intervention development, following the steps of the BCW, including data collection and interpretation, was performed by SDG and JR with involvement of $L L, A T, S V$ and FD. The manuscript was written by JR with regular revision and feedback from SDG and LL. Before publication the final revision was reviewed and approved by all co-authors.

\section{Funding}

The overall SMILe research project is funded by the B. Braun Foundation, the Jose Carreras Foundation, the Federal Ministry of Education and Research (Germany) and the Swiss Cancer League. The funders had no role in study design, data collection, analysis, interpretation and writing the report.

\section{Availability of data and materials}

The data of the previously performed contextual analysis included in the development of the intervention were recently published by $L L$ and our research group [36]. As the original data is personal and cannot be completely anonymized, it cannot be made available for open access. Other data analyzed and synthesized are available from the corresponding author upon request.

\section{Ethics approval and consent to participate}

The prototype development of the SMILe-V1 Care Model Prototype-FiB including multi-methods contextual analysis and user tests was approved by the Ethics Committee of Freiburg, Germany (EK67/17). All participants signed informed consent.

\section{Consent for publication}

Not applicable.

\section{Competing interests}

The authors declare that they have no competing interests.

\section{Author details}

${ }^{1}$ Department Public Health, Faculty of Medicine, Institute of Nursing Science, University of Basel, Bernoullistrasse 28, 4056 Basel, Switzerland. ${ }^{2}$ Department of Hematology, University Hospital of Basel, 4031 Basel, Switzerland. ${ }^{3}$ Departments of Hematology, Oncology and Stem Cell Transplantation, University Medical Center Freiburg, 79110 Freiburg im Breisgau, Germany. ${ }^{4}$ Department of Computer Science, University of Applied Sciences, Augsburg, Germany. ${ }^{5}$ Academic Center for Nursing and Midwifery, Department of Public Health and Primary Care, University of Leuven, 3000 Leuven, Belgium.
${ }^{6}$ Department of Population Health Science, Duke University, Durham, NC, USA. ${ }^{7}$ Center of Innovation to Accelerate Discovery and Practice Transformation (ADAPT), Durham Veterans Affairs Health Care System, Durham, NC, USA.

Received: 10 January 2020 Accepted: 9 August 2020

Published online: 02 September 2020

\section{References}

1. Maedler-Kron C, Marcus VA, Michel RP. Hematopoietic Stem Cell Transplantation. In: Michel RP, Berry GJ, editors. Pathology of Transplantation: A Practical Diagnostic Approach. Cham: Springer International Publishing; 2016. p. 401-49.

2. Bevans M, El-Jawahri A, Tierney DK, Wiener L, Wood WA, Hoodin F, et al. National Institutes of Health hematopoietic cell transplantation late effects initiative: the patient-centered outcomes working group report. Biol Blood Marrow Transplant. 2017;23(4):538-51.

3. Gee PM, Greenwood DA, Paterniti DA, Ward D, Miller LMS. The eHealth enhanced chronic care model: a theory derivation approach. J Med Internet Res. 2015;17(4):e86.

4. De Geest S, Zullig LL, Dunbar-Jacob J, Helmy R, Hughes DA, Wilson IB, et al. ESPACOMP medication adherence reporting guideline (EMERGE). Ann Intern Med. 2018;169:30-5.

5. Vrijens B, De Geest S, Hughes DA, Przemyslaw K, Demonceau J, Ruppar T, et al. A new taxonomy for describing and defining adherence to medications. Br J Clin Pharmacol. 2012;73(5):691-705.

6. Smith A, Wisloff F, Samson D. Guidelines on the diagnosis and management of multiple myeloma 2005. Br J Haematol. 2006;132(4):410-51.

7. Tomblyn M, Chiller T, Einsele H, Gress R, Sepkowitz K, Storek J, et al. Guidelines for preventing infectious complications among hematopoietic cell transplant recipients: a global perspective. Bone Marrow Transplant. 2009;44(8):453.

8. Tabbara IA, Zimmerman K, Morgan C, Nahleh Z. Allogeneic hematopoietic stem cell transplantation: complications and results. Arch Intern Med. 2002; 162(14):1558-66.

9. Hilgendorf I, Greinix H, Halter JP, Lawitschka A, Bertz H, Wolff D. Long-term follow-up after allogeneic stem cell transplantation. Dtsch Arztebl Int. 2015; 112(4):51.

10. Wingard JR, Majhail NS, Brazauskas R, Wang Z, Sobocinski KA, Jacobsohn D, et al. Long-term survival and late deaths after allogeneic hem-atopoietic cell transplantation. J Clin Oncol. 2011;29:2230-9.

11. Wood WA, Chai X, Weisdorf D, Martin PJ, Cutler C, Inamoto Y, et al. Comorbidity burden in patients with chronic GVHD. Bone Marrow Transplant. 2013:48:1429-36.

12. Gresch B, Kirsch M, Fierz K, Halter JP, Nair G, Denhaerynck K, et al. Medication nonadherence to immunosuppressants after adult allogeneic haematopoietic stem cell transplantation: a multicentre cross-sectional study. Bone Marrow Transplant. 2017;52(2):304.

13. Kirsch M, Götz A, Halter JP, Schanz U, Stussi G, Dobbels F, et al. Differences in health behaviour between recipients of allogeneic haematopoietic SCT and the general population: a matched control study. Bone Marrow Transplant. 2014;49(9):1223.

14. Flodgren G, Rachas A, Farmer AJ, Inzitari M, Shepperd S. Interactive telemedicine: effects on professional practice and health care outcomes. Cochrane Database Syst Rev. 2015;9:CD002098.

15. Dobbels F, De Bleser L, Berben L, Kristanto P, Dupont L, Nevens F, et al. Efficacy of a medication adherence enhancing intervention in transplantation: the MAESTRO-Tx trial. J Heart Lung Transplant. 2017;36(5): 499-508.

16. Schmid A, Hils S, Kramer-Zucker A, Bogatyreva L, Hauschke D, De Geest $S$, et al. Telemedically supported case Management of Living-Donor Renal Transplant Recipients to optimize routine evidence-based aftercare: a single-center randomized controlled trial. Am J Transplant. 2017;17(6):1594-605.

17. Linn AJ, Vervloet M, van Dijk L, Smit EG, Van Weert JC. Effects of eHealth interventions on medication adherence: a systematic review of the literature. J Med Internet Res. 2011;13(4):e103.

18. De Bleser L, Matteson M, Dobbels F, Russell C, De Geest S. Interventions to improve medication-adherence after transplantation: a systematic review. Transpl Int. 2009;22(8):780-97. 
19. Low JK, Williams A, Manias E, Crawford K. Interventions to improve medication adherence in adult kidney transplant recipients: a systematic review. Nephrol Dial Transplant. 2014;30(5):752-61.

20. Welch MA, Kaled ES. Ensuring optimal adherence to BCR-ABL1 tyrosine kinase inhibitor therapy for chronic myeloid leukemia. Commun Oncol. 2013;10(5):138-46.

21. Zullig LL, Deschodt M, Liska J, Bosworth H, De Geest S. Moving from the trial to the real world: improving medication adherence using insights of implementation science. Annu Rev Pharmacol Toxicol. 2019;59:423-45.

22. Ahmed I, Ahmad NS, Ali S, Ali S, George A, Danish HS, et al. Medication adherence apps: review and content analysis. JMIR mHealth and uHealth. 2018;6:e62.

23. Morrissey EC, Corbett TK, Walsh JC, Molloy GJ. Behavior change techniques in apps for medication adherence: a content analysis. Am J Prev Med. 2016; 50(5):e143-6.

24. Aitken M, Clancy B, Nass D. The growing value of digital health. IQVIA Institute for Human Data Science. 2017:1-76.

25. Webb T, Joseph J, Yardley L, Michie S. Using the internet to promote health behavior change: a systematic review and meta-analysis of the impact of theoretical basis, use of behavior change techniques, and mode of delivery on efficacy. J Med Internet Res. 2010;12:e4.

26. Prendergast MB, Gaston RS. Optimizing medication adherence: an ongoing opportunity to improve outcomes after kidney transplantation. Clin J Am Soc Nephrol. 2010;5(7):1305-11.

27. Damschroder LJ, Aron DC, Keith RE, Kirsh SR, Alexander JA, Lowery JC. Fostering implementation of health services research findings into practice: a consolidated framework for advancing implementation science. Implement Sci. 2009;4(1):50.

28. Horne R, Weinman J, Barber N, Elliott R, Morgan M, Cribb A, et al. Concordance, adherence and compliance in medicine taking. London: NCCSDO; 2005:40-6.

29. Demonceau J, Ruppar T, Kristanto P, Hughes DA, Fargher E, Kardas P, et al. Identification and assessment of adherence-enhancing interventions in studies assessing medication adherence through electronically compiled drug dosing histories: a systematic literature review and meta-analysis. Drugs. 2013;73(6):545-62.

30. McDonald HP, Garg AX, Haynes RB. Interventions to enhance patient adherence to medication prescriptions: scientific review. Jama. 2002;288(22): 2868-79.

31. Nieuwlaat R, Wilczynski N, Navarro T, Hobson N, Jeffery R, Keepanasseril A, et al. Interventions for enhancing medication adherence. Cochrane Database Syst Rev. 2014;2014(11):CD000011.

32. Peterson AM, Takiya L, Finley R. Meta-analysis of trials of interventions to improve medication adherence. Am J Health Syst Pharm. 2003;60(7):657-65.

33. West R. Theory of addiction. Oxford: Blackwells; 2006.

34. Michie S, Van Stralen MM, West R. The behaviour change wheel: a new method for characterising and designing behaviour change interventions. Implement Sci. 2011;6(1):42.

35. Abrahamsson P, Salo O, Ronkainen J, Warsta J. Agile software development methods: Review and analysis. Espoo: VTT publication 478; 2017.

36. Leppla L, Mielke J, Kunze M, Mauthner O, Teynor A, Valenta S, et al. Clinicians and patients perspectives on follow-up care and eHealth support after allogeneic hematopoietic stem cell transplantation: a mixed-methods contextual analysis as part of the SMILe study. Eur J Oncol Nurs. 2020;45:101723.

37. Murphy M, McCloughen A, Curtis K. Using theories of behaviour change to transition multidisciplinary trauma team training from the training environment to clinical practice. Implement Sci. 2019;14:43.

38. Jackson C, Eliasson L, Barber N, Weinman J. Applying COM-B to medication adherence: a suggested framework for research and interventions. European Health Psychologist. 2014;16(1):7-17.

39. Bixby DL. Managing inadequate responses to frontline treatment of chronic myeloid leukemia: a case-based review. Cancer Treat Rev. 2012; 39(3):241-51.

40. Talati C, Ontiveros EP, Griffiths EA, Wang ES, Wetzler M. How we will treat chronic myeloid leukemia in 2016. Blood Rev. 2015;29(2):137-42.

41. Lehrer J, Brissot E, Ruggeri A, Dulery R, Vekhoff A, Battipaglia G, et al. Medication adherence among allogeneic hematopoietic stem cell transplant recipients: a pilot single-center study. Bone Marrow Transplant. 2018;53(2):231-3.

42. Bertz H, Finke J. Transplant manual: Hämatopoetische Zelltransplantation (HZT). Freiburg: University Hospital of Freiburg; 2016.
43. Hoodin F. Psychological and behavioral correlates of medical adherence among adult bone marrow transplant recipients. Detroit: Wayne State University; 1995.

44. Montesinos P, Rodríguez-Veiga R, Boluda B, Martínez-Cuadrón D, Cano I, Lancharro $A$, et al. Incidence and risk factors of post-engraftment invasive fungal disease in adult allogeneic hematopoietic stem cell transplant recipients receiving oral azoles prophylaxis. Bone Marrow Transplant. 2015; 50:1465-72.

45. Schäfer-Keller P, Steiger J, Bock A, Denhaerynck K, De Geest S. Diagnostic accuracy of measurement methods to assess nonadherence to immunosuppressive drugs in kidney transplant recipients. Am J Transplant. 2008;8:616-26.

46. De Geest S, Abraham I, Moons P, Vandeputte M, Van Cleemput J, Evers G, et al Late acute rejection and subclinical noncompliance with cyclosporine therapy in heart transplant recipients. J Heart Lung Transplant. 1998;17:854-63.

47. Pinsky BW, Takemoto SK, Lentine KL, Burroughs TE, Schnitzler MA, Salvalaggio PR. Transplant outcomes and economic costs associated with patient noncompliance to immunosuppression. Am J Transplant. 2009;9: 2597-606.

48. Muduma G, Shupo FC, Dam S, Hawken NA, Aballea S, Odeyemi I, et al. Patient survey to identify reasons for non-adherence and elicitation of quality of life concepts associated with immunosuppressant therapy in kidney transplant recipients. Patient Prefer Adherence. 2016;10:27.

49. Tong A, Howell M, Wong G, Webster AC, Howard K, Craig JC. The perspectives of kidney transplant recipients on medicine taking: a systematic review of qualitative studies. Nephrol Dial Transplant. 2010;26(1): 344-54.

50. Williams A, Low JK, Manias E, Crawford K. The transplant team's support of kidney transplant recipients to take their prescribed medications: a collective responsibility. J Clin Nurs. 2016;25(15-16):2251-61.

51. Rebafka A. Medication adherence after renal transplantation-a review of the literature. J Ren Care. 2016;42(4):239-56.

52. Jamieson NJ, Hanson CS, Josephson MA, Gordon EJ, Craig JC, Halleck F, et al. Motivations, challenges, and attitudes to self-management in kidney transplant recipients: a systematic review of qualitative studies. Am J Kidney Dis. 2016;67(3):461-78.

53. O'Grady JG, Asderakis A, Bradley R, Burnapp L, McPake DM, Perrin M, et al. Multidisciplinary insights into optimizing adherence after solid organ transplantation. Transplantation. 2010;89(5):627-32.

54. Tong A, Morton RL, Webster AC. How qualitative research informs clinical and policy decision making in transplantation: a review. Transplantation. 2016;100(9):1997-2005.

55. Pinter J, Hanson CS, Craig JC, Chapman JR, Budde K, Halleck F, et al. 'I feel stronger and younger all the time'-perspectives of elderly kidney transplant recipients: thematic synthesis of qualitative research. Nephrol Dial Transplant. 2016;31(9):1531-40.

56. Low JK, Crawford K, Manias E, Williams A. Stressors and coping resources of Australian kidney transplant recipients related to medication taking: a qualitative study. J Clin Nurs. 2017;26(11-12):1495-507.

57. Israni A, Dean C, Kasel B, Berndt L, Wildebush W, Wang CJ. Why do patients forget to take immunosuppression medications and miss appointments: can a mobile phone app help? JMIR Public Health Surveill. 2016;2(1):e15.

58. Low JK, Crawford K, Manias E, Williams A. A compilation of consumers' stories: the development of a video to enhance medication adherence in newly transplanted kidney recipients. J Adv Nurs. 2016;72(4):813-24.

59. Janelle C, O'Connor K, Dupuis G. Evaluating illness representations in heart transplant patients. J Health Psychol. 2016;21(9):1850-9.

60. Williams A, Crawford K, Manias E, Ellis C, Mullins K, Howe K, et al. Examining the preparation and ongoing support of adults to take their medications as prescribed in kidney transplantation. J Eval Clin Pract. 2015;21(2):180-6.

61. Ivarsson B, Ekmehag B, Sjöberg T. Patients' experiences of information and support during the first six months after heart or lung transplantation. Eur J Cardiovasc Nurs. 2013;12(4):400-6.

62. Denhaerynck K, Berben L, Dobbels F, Russell CL, Crespo-Leiro MG, Poncelet $\mathrm{AJ}$, et al. Multilevel factors are associated with immunosuppressant nonadherence in heart transplant recipients: the international BRIGHT study. Am J Transplant. 2018;18(6):1447-60.

63. Boaz A, Morgan M. Working to establish 'normality'post-transplant: a qualitative study of kidney transplant patients. Chronic illn. 2014;10(4):247-58.

64. De Geest S, Burkhalter H, Bogert L, Berben L, Glass TR, Denhaerynck K, et al. Describing the evolution of medication nonadherence from pretransplant 
until 3 years post-transplant nonadherence to immunosuppressives: the Swiss transplant cohort study. Transpl Int. 2014;27:657-66.

65. Cooke L, Chung C, Grant M. Psychosocial Care for Adolescent and Young Adult Hematopoietic Cell Transplant Patients. J Psychosoc Oncol. 2011;29(4):394-414.

66. Michie $S$, Atkins $L$, West $R$. The behaviour change wheel : a guide to designing interventions. Great Britain: Silverback Publishing; 2014.

67. Brito Félix I, Pereira Guerreiro M, Cavaco A, Paula Cláudio A, Mendes A, Balsa $J$, et al. Development of a complex intervention to improve adherence to antidiabetic medication in older people using an anthropomorphic virtual assistant software. Front Pharmacol. 2019;10:680

68. Lucas B, Brammen D, Schirrmeister W, Aleyt J, Kulla M, Roehrig R, et al. Requirements for a sustainable standardization and digitalization in clinical emergency and acute medicine. Unfallchirurg. 2019;122:243-6.

69. Conn VS, Enriquez M, Ruppar TM, Chan KC. Meta-analyses of theory use in medication adherence intervention research. Am J Health Behav. 2016;40: 155-71.

70. Lyon AR, Bruns EJ. User-centered redesign of evidence-based psycho-social interventions to enhance implementation — hospitable soil or better seeds? JAMA Psychiatry. 2019;76(1):-4.

71. Yzer M. The integrative model of behavioral prediction as a tool for designing health messages. In: Hyuniyi C, editor. Health communication message design: Theory and practice; 2012. p. 21-40.

72. Michie S, Richardson M, Johnston M, Abraham C, Francis J, Hardeman W, et al. The behavior change technique taxonomy (v1) of 93 hierarchically clustered techniques: building an international consensus for the reporting of beh. Ann Behav Med. 2013;46:81-95.

73. Möhler R, Köpke S, Meyer G. Criteria for reporting the development and evaluation of complex interventions in healthcare: revised guideline (CReDECI 2). Trials. 2015;16(1):204

74. Hoffmann TC, Glasziou PP, Boutron I, Milne R, Perera R, Moher D, et al. Better reporting of interventions: template for intervention description and replication (TIDieR) checklist and guide. Bmj. 2014;348:g1687.

\section{Publisher's Note}

Springer Nature remains neutral with regard to jurisdictional claims in published maps and institutional affiliations.

Ready to submit your research? Choose BMC and benefit from:

- fast, convenient online submission

- thorough peer review by experienced researchers in your field

- rapid publication on acceptance

- support for research data, including large and complex data types

- gold Open Access which fosters wider collaboration and increased citations

- maximum visibility for your research: over $100 \mathrm{M}$ website views per year

At $\mathrm{BMC}$, research is always in progress.

Learn more biomedcentral.com/submissions 